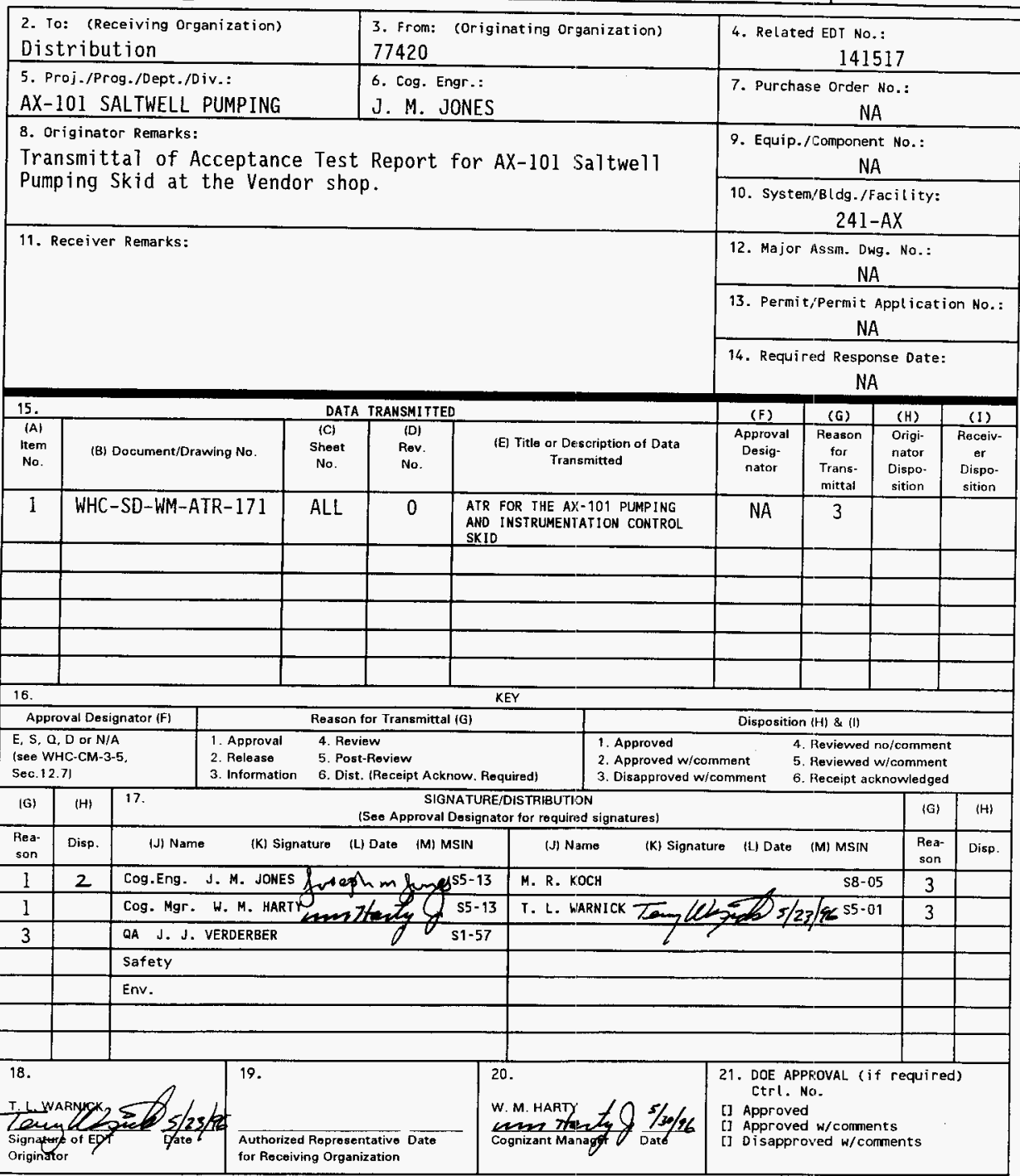




\title{
ATR FOR THE AX-101 PUMPING AND INSTRUMENTATION CONTROL SKID
}

\section{S. K. KUJAK}

WESTINGHOUSE HANFORD COMPANY, Richland, WA 99352

U.S. Department of Energy Contract DE-ACO6-87RL10930

\author{
EDT/ECN: $150294 \quad$ UC: 2030 \\ Org Code: $77420 \quad$ Charge Code: N1654 \\ B\&R Code:EW31200/7 Total Pages: 84
}

Key Words: Operator Control Station, Analog Signal Verification, Discrete Signal Verification, Monitor and Alarm Function Verification, Remote Setpoint Change, Remote Jetpump Shutdown, PICS Skid Test

Abstract: This Acceptance Test Report presents the results of the acceptance test performed at the shop on the monitor and control functions of the AX-101 Saltwell Pumping PICS skid. This work supports the interim stabilization of tank $241-A X-101$.

TRADEMARK DISCLAIMER. Reference herein to any specific comercial product, process, or service by trade name, trademark, manufacturer, or otherwise, does not necessarily constitute or imply its endorsement, recommendation, or favoring by the United States Government or any agency thereof or its contractors or subcontractors.

Printed in the United States of America. To obtain copies of this document, contact: WHC/BCS Document Control Services, P.O. Box 1970, Mailstop H6-138, Richland WA 99352, Phone (509) 372-2420; Fax (509) 376-4989.
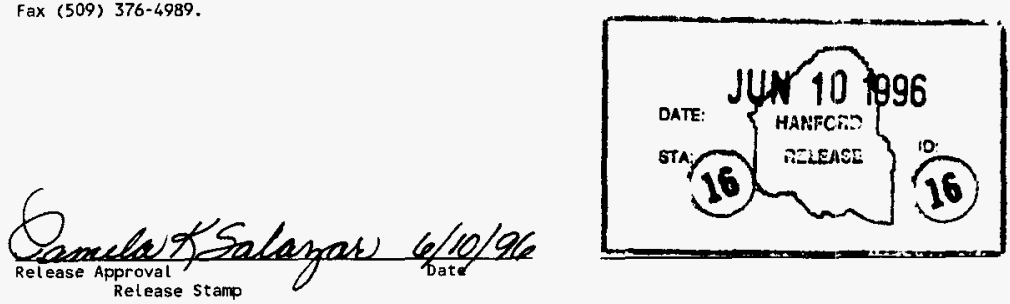

\section{Approved for Public Release}


TANK FARM

ACCEPTANCE TEST REPORT

\section{SYSTEM}

INTERIM STABILIZATION

ATR FOR THE AX-101 PUMPING AND INSTRUMENTATION CONTROL SKID 


\section{TANK FARM ACCEPTANCE TEST PROCEDURE}

\section{TEST EXECUTION SHEET}

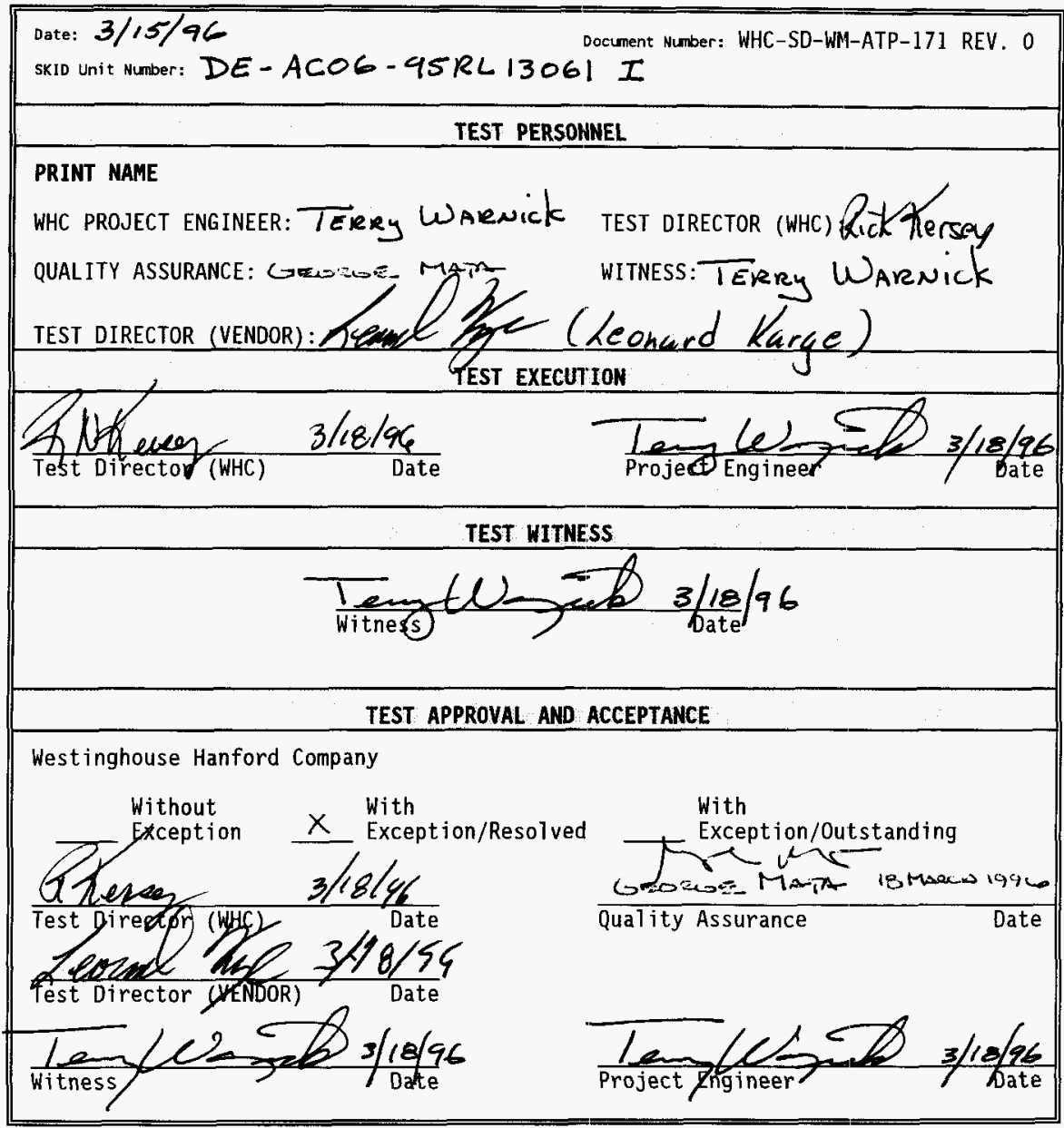




\section{TABLE OF CONTENTS}

PAGE

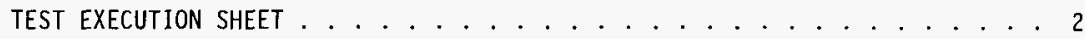

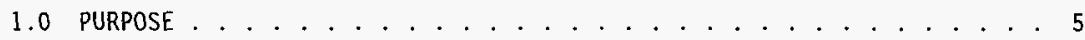

2.0 INFORMATION . . . . . . . . . . . . . . . . . . 6

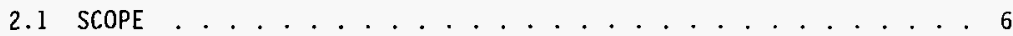

2.2 TERMS AND DEFINITIONS . . . . . . . . . . . . . 10

2.3 RESPONSIBILITIES . . . . . . . . . . . . . 11

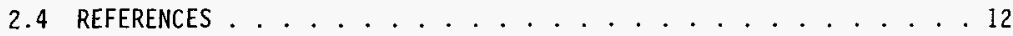

2.5 SAFETY . . . . . . . . . . . . . . . . 12

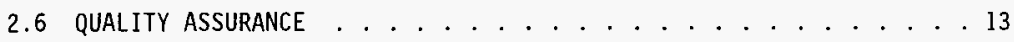

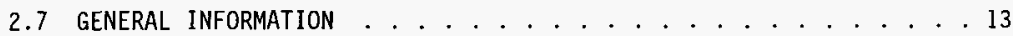

3.0 RECORDS . . . . . . . . . . . . . . . . . . 14

4.0 PREREQUISITES . . . . . . . . . . . . . . . . . 15

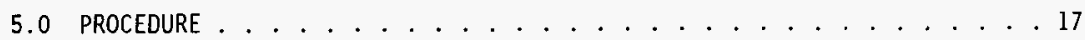

5.1 PICS ELECTRICAL AND PROCESS AIR POWER UP . . . . . . . . 17

5.2 PICS WATER DRIP SYSTEM . . . . . . . . . . . . . . . 22

5.3 WEIGHT FACTOR AND SPECIFIC GRAVITY SYSTEM . . . . . . . . 25

5.4 doV AUTOMATIC AND MANUAL CONTROL . . . . . . . . . . . 29

5.5 JET PUMP FLOWMETER OPERATION . . . . . . . . . . . . . 34

5.6 WATER TANK LEVEL TRANSMITTER . . . . . . . . . . . . . 38

5.7 JET PUMP HEAT TRACE AND INSTRUMENT TEMPERATURE $\ldots \ldots . \ldots . \ldots$

5.8 INTERLOCKS . . . . . . . . . . . . . . . . . 44

5.9 JET PUMP VALVING INTERLOCK . . . . . . . . . . . 58

0


TABLE OF CONTENTS (Cont inued)

PAGE

FIGURE 1 - FLOW DIAGRAM INSTRUMENT AIR AND WATER SYSTEMS . . . . . . . . . 61

FIGURE 2 - WEIGHT FACTOR INSTRUMENT ENCL_OSURE FLOW SHEET . . . . . . . . . 62

FIGURE 3 - JUMPER TEST ASSEMBLY . . . . . . . . . . . . . . . . 63

FIGURE 4 - JET PUMP JUMPER TEST CONNECTIONS . . . . . . . . . . . . . 64

ATP EXCEPTION LOG . . . . . . . . . . . . . . . . . . . . . . 65

ATP EXCEPTION RECORD . . . . . . . . . . . . . . . . . . . 66

ATP ACCEPTANCE RECORD . . . . . . . . . . . . . . . . . . . . . . . 67

APPENDIX-PICS LEAK TEST PROCEDURE A-1 


\subsection{PURPOSE}

1.1 The purpose of this Acceptance Test Procedure (ATP) is to provide a record of functional testing results and verification that requirements specified for the Saltwell Pumping Instrument skids meet operational requirements of the buyer (WHC).

1.2 This ATP shall verify and document that the Vendor fabricated skid system operates as a stand alone unit under control of local operator interface. A jet pump assembly (JPA) will be connected to the skid system for testing the total system as it would be connected in the field.

1.3 The following systems will be tested by this ATP:

- PICS Electrical and Process Air System

- PICS Water Drip System

- Weight Factor and Specific Gravity System

- DOV Automatic and Manual Operation

- Jet pump Flowmeter Operation

- Water Tank Level Transmitter

- Jet pump Heat Trace and Instrument Temperature

- Interlocks

- Jet Pump Valving Interlock 


\subsection{INFORMATION}

\section{$2.1 \quad$ SCOPE}

\subsubsection{DIP TUBES}

Saltwell liquid levels are determined by analyzing specific gravity and weight factor data obtained from three dip tubes (tubes projecting into a tank to varying levels). The high pressure dip tube extends to within a few inches of the bottom of the tank. The medium pressure dip tube is 10 inches shorter than the high pressure tube. The low pressure dip tube measures ambient pressure above the liquid in the tank. Air is constantly supplied at a low flow rate through each tube by the instrument air system on the skid.

The dip tubes are connected to the Weight Factor and Specific Gravity System. It is this system which measures the differential pressures that exist between the three Dip Tubes. This system consists of two electronic differential pressure transmitters which convert the measured differential pressures into an electronic signal, representative of the liquid's weight factor and specific gravity.

\subsubsection{WATER DRIP SYSTEM}

The air flow through each dip tube is monitored by a rotameter and controlled by a valve on each rotameter. Water is added at a low flow rate to the medium and high pressure dip tubes to ensure that no waste salts crystallize in the dip tubes and cause a blockage. The water flow rate is monitored by use of an in-line sight glass.

Rev/Mod




\subsubsection{WEIGHT FACTOR AND SPECIFIC GRAVITY TRANSMITTERS}

Weight Factor Indicator (WFI): Weight factor readings are obtained by measuring the pressure difference between the high and low pressure tubes. The pressure difference is sensed by the WFI. The WFI converts the pressure difference to a 4 to $20 \mathrm{ma}$ instrument signal used as indication of saltwell level. The analog signal from the WFI is sent via shielded pair cable to an analog input of the PLC in the skid instrument cabinet.

Specific Gravity Indicator (SGI): Specific gravity readings are obtained by measuring the pressure difference between the high and medium pressure dip tubes. The pressure difference is sensed by the SGI. The SGI converts the pressure difference to a 4 to $20 \mathrm{ma}$ analog instrument signal which is sent via shielded pair cable to an analog input of the PLC on the skid.

\subsubsection{DIAPHRAGM OPERATED VALVE}

The Diaphragm Operated Valve (DOV) on the jet pump jumper is used to control the flow rate of liquid thirough the jet pump jumper. When the DOV is open some of the liquid being pumped, which is normally recirculated through the jet, is sent out the transfer line to the designated receiver tank.

\subsubsection{FLOWMETER}

A Johnson Yokogawa magnetic flowmeter measures the flow rate of material out of the jet pump jumper and transmits a data signal to the FQIT. The FQIT converts the flow signal data to a 4 to $20 \mathrm{ma}$ instrument signal sent via shielded, twisted pair cable to an analog input of the PLC on the skid.

\begin{tabular}{|l|l|l|}
\hline $\begin{array}{l}\text { Document No. } \\
\text { WHC-SD-WM-ATR-171 }\end{array}$ & Rev/Mod & Page \\
\hline
\end{tabular}




\subsubsection{LIMIT SHITCHES}

The jet pump jumper is supplied with two limit switches. Both 1 imit switches are activated by three-way valve, JR-1, to prevent the miss-routing of process fluid. Limit switch, LS-1, in conjunction with a time delay software timer, allows the pumps on a common transfer line to operate for 30 minutes after one puinp shuts down. Pumps on the same header will continue to operate if the JR-1 valve on the shutdown pump is in the prime position. All pumps on a common header will shutdown and cannot be restarted if any common header pump's JR-1 valve is in the flush position. LS-2 is (open) whenever the JR-1 valve is in the flush position. While open it prevents any saltwell pumps on a common header from starting and immediately shuts down any running pumps. In normal process operation, the valve actuator arm opens the LS- 1 and closes LS-2, and the indicator light on the instrument panel shows normal operation. The three-way valve has three positions: prime, flush, and pump (or process normal).

\subsubsection{PRESSURE SWITCHES}

Pressure switch PS-1 provides for pump shutdown interlock when pump discharge pressure falls and remains below 15 psig for 30 seconds. The pressure switch designated PS-2 monitors the flush 1 ine pressure. PS-2 will stop the pump when the flush line pressure rises above 10 psig. PS-1-1 provides shutdown interlock for this system, usually activated by high pressure in the circulation loop at approximately $185 \mathrm{psig.} \mathrm{Activation} \mathrm{of} \mathrm{any} \mathrm{above} \mathrm{switch} \mathrm{will}$ also initiate an assciciated alarm.

A11 of the pressure switches shall be calibrated prior to any tests or pressurization of jet pump jumper assembly.

\subsubsection{INSTRUMENT AIR SYSTEM}

The Instrument Air system is mounted on the PICS. It contains an air compressor, holding tank, air vaiving, and controls. The Instrument Air system provides air to Weight Factor Instrument Enclosure (WFIE) for the dip tubes and air to the PICS water system.

The compressor is powered by 480 VAC 3 phase motor and the pressure is regulated by a pressure switch. The instrument air is filtered and dried prior to being sent to the instruments. Air pressure is maintained between 60 and 90 psig.

\begin{tabular}{l|l} 
Page \\
\hline
\end{tabular}




\subsubsection{POWER CONTROL STATION}

The PICS is powered from a Tank Farm 480 VAC supply. Motor controllers are provided for the saltwell pump and the air compressor. A stepdown transformer provides 120/240 VAC for instrumentation and control. Power receptacles are available for tools, and a light system for nighttime illumination.

\subsubsection{PUMP PRESSURE TRANSDUCERS}

The pump suction and discharge transducers are used to monitor pump discharge and suction. The suction transmitter has a range of -10 to $80 \mathrm{psig}$ and the discharge transmitter has a range of 0 to $150 \mathrm{psig}$. Both transmitters produce a 4 to $20 \mathrm{~mA}$ output. 


\subsection{TERMS AND DEFINITIONS}

2.2.1 CT - Connector

2.2.2 CW - Clockwise

2.2.3 CCW - Counter $\underline{\text { Clockwise }}$

2.2.4 DB - Dead Band

2.2.5 DOV - Diaphragm ㅁpperated Valve

2.2.6 DTAM - Data Iransfer And Monitor

2.2.7 ECN - Engineering Change Notice

2.2.8 EPC - Electro-Pneumatic Converter

2.2.9 FI - Flow Indicator

2.2.10 FGM - Elammable Gas Monitor

2.2.11 FM - Elowmeter

2.2.12 FQIT - Elow Iotalizing Indicating Iransmitter

2.2.13 FS - Eull scale

2.2.14 GF - Sight $\underline{\text { Gl ass }}$

2.2.15 GPM - Ga7lons Per Minute

2.2.16 IA - Instrument Air

2.2.17 LS - Limit Switch

2.2.18 LOS - Leak Detection Station

2.2.19 LDE - Leak Detection Element

2.2.20 MCC - Motor Control Center

2.2.21 MR - Manometer

2.2.22 MTC - Motor Iemperatiure C्Cutout

2.2.23 ATP - Acceptance Iest Procedure

2.2.24 PIC - Person In harge

2.2.25 PICS - pumping and Instrumentation Control śkid

2.2.26 PLC - Programmable Logic Controler

0

Page

10


2.2.27 PRV - Pressure Regulating Valve

2.2.28 PS - Pressure $\underline{\text { Switich }}$

2.2.29 RV - Relief Valve

2.2.30 RW - Raw Water

2.2.31 RWP - Radiation Whork Permit

2.2.32 SGI - Specific Gravity Indicator

2.2.33 SRV - Safety Relief Valve

2.2.34 TFO - Iank Farm Operations

2.2.35 WFIE - Weight Factor Instrument Enclosure

2.2.36 WFI - Weight Factor Indicator

2.2.37WG - Water Gauge

\subsection{RESPONSIBILITIES}

2.3.1 The Maintenance craft personnel are responsible for:

- Providing assistarce during the test.

2.3.2 Quality Control (QC) is responsible for:

- Witnessing and signing steps as identified in ATP.

- Verifying that the procedure sections were performed correctiy.

- Signing and dating test exception and approval sheets.

2.3.3 Test Director (WHC)

- Provides the equipment found in step 4.1 of this procedure.

- Records equipment status and data per this procedure.

- Conducts pre-job planning meeting as necessary.

- Conducts pre-job system walkdown.

- Recording data, exceptions and other notes as required on the ATP Data Sheets.

\subsubsection{Test Coordinator (Vendor)}

- Coordinating ATP with Test director.

- Scheduling/rescheduling of the test as required.

0




\subsection{RESPONSIBILITIES (cont inued)}

2.3.5 Witness is responsible for:

- Witness the tests.

- Evaluate results of testing.

- Assist the Test Director when requested.

- Sign Test Exception Sheet as a witness.

- Sign Test Exception Sheet as a witness when retest has been executed and accepted.

2.3.6 Cognizant Engineer is responsible for:

- Making redline changes to this procedure.

- Approving Test Exception resolution(s).

- Signing ATP ACCEPTANCE RECORD.

\subsection{REFERENCES}

2.4.1 The following documents were used to write or are referenced in this procedure:

- WHC-CM-1-10, SAFETY MANUAL, WKS-6, "PRE-JOB SAFETY PLANNING", "WKS-15, ELECTRICAL WORK SAFETY"

- WHC-CM-6-1 EP 4.2., STANDARD ENGINEERING PRACTICE "TESTING PRACTICES"

- WHC-IP-1026 APPX L., "ENGINEERING PRACTICES GUIDELINES"

- H-14-100723 Rev 0, INSTRUMENT AIR AND WATER DETAILS

- H-14-100724 Rev 0, INSTRUMENTATION WEIGHT FACTOR ENCLOSURE ARRANGENENT

- H-14-100725 Rev 0, INSTRUMENT ENCLOSURE WIRING DIAGRAM

- H-14-023908 Rev 0, ENGINEERING FLOW DIAGRAM SALT WELL PUMPING SYSTEM

- H-14-023909 Rev 0, ENGINEERING FLOW DIAGRAM SALTWELL DIP TUBE AIR AND WATER SYSTEM

- JOHNSON YOKOGAWA AOMAG AM SERIES VENDOR INFORMATION

- FOXBORO 823 DP SERIES ELECTRONIC DIFFERENTIAL PRESSURE CELL VENDOR INFORMATION

- YOKOGAWA 4153 THREE PEN RECORDER VENDOR INFORMATION

\subsection{SAFETY}

Warning - Circuit boards are energized. Terminal strips in the Instrument Enclosure have 120 VAC exposed leads. Observe appropriate electrical precautions.

Warning - Energized circuits and leads are contained inside the cabinet.

0




\subsection{QUALITY ASSURANCE}

See QC resposibilities in section 2.3.

\subsection{GENERAL INFORMATION}

2.7.1 Complete each procedure step in the given order, unless otherwise noted or as directed by the Test Director.

2.7.2 All entries recorded in this procedure shall be made in black ink.

2.7.3 Editorial changes required to this ATP may be made per the red line method by the Test Director and Cognizant Engineer as long as they do not impact operational facility safety function, or performance and will not compromise or influence the test data. Any changes affecting the above stated criteria shall be made in accordance with WHC-CM-6-1, Standard Engineering Practices, EP-2.2 Change Control.

2.7.4 Any non-conformance of the instrumentation or unexpected results during testing shall be logged in the ATP EXCEPTION LOG and thoroughly documented on a ATP EXCEPTION RECORD.

2.7.5 Do not perform any part of this procedure on faulty equipment. If fautty equipment is discovered, STOP the execution of this procedure and resolve the problem.

2.7.6 If the performance of this procedure is suspended for any reason, ensure the equipment is left in a safe and de-energized state as necessary.

2.7.7 This procedure DOES NOT contain any separate data/verification sheets. Verification of procedural steps and validity of the data is incorporated into the specific section.

2.7.8 Minor air and water leaks will be repaired during the Pre-Test section of the ATP. The intent of this ATP is to provide a method for documenting the condition and capabilities of the as-built PICS unit. The attached ATP Exception Log and Exception Record provides the means of documenting Acceptance Testing results and equipment conditions. Additional sheets are to be used as necessary to delineate the progress of the ATP.

WHC-SD 


\subsection{RECORDS}

3.1. The completed working copy of this procedure and a 17 exception logs and exception records generated by this procedure, will be kept as permanent records.

3.2 In the event minor drawing changes are required to successfutly complete this ATP, such as chariging a relay contact from Normally Open (NO) to Normally Closed (NC), the change shall be noted as an exception and incorporated in an ECN after the completion of this ATP.

Johnson Yokogawa \& Yokogawa are trademarks of the Johnson Yokogawa Corporation. 


\section{TANK FARM ACCEPTANCE TEST PROCEDURE}

\subsection{PREREQUISITES}

4.1 The following supplies shall be available at the workplace:

- Voltohmmeter (VOM): Portable, 0-600 volts ac, $\pm 2 \%$ accuracy. Calibration No. WEi-4s-os-cor2 Expiration Date $12 / 12 / 96$

- Thermocouple Voltage Source (West Portable Potentiometer or equivalent).

Calibration No. $34-13-55.001$ Expiration Date $11 / 21 / 96$

- Transmation current (milliamp) simulator or equivalent

Calibration No. 6si-13.20.001 Expiration Date lo/zu/ace

- Rotameter or Flowmeter

- Manometer - minimum range 0-500" water gauge. Must have a read out of variable test pressure.

Calibration No. $899-35-40-005$ Expiration Date $0.131 / 97$

- Manometer - minimum range 0-20" water gauge. Must have a read out of variable test pressure.

Calibration No. 849-35.40.

- Saltwel1 Jet pump Jumper

- Jumper Test Assembly (see Figure 3)

- Pan or bucket with water (6" diameter and $3 "$ deep).

- 480V 3 Phase Power Source

4.1.1 Test Director SHALL VERIFY that section 4.1 is complete by signing below.

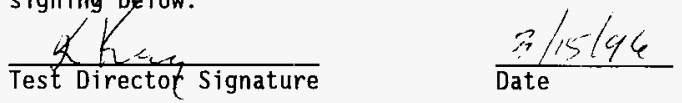

4.1.2 QC Inspector SHALL VERIFY that section 4.1 is complete by signing below.

$\frac{\text { ceocuz MATt }}{\text { QC Inspector Signature }} \quad \frac{3|, 5| q 6}{\text { Date }}$




\subsection{PREREQUISITES (Cont inued)}

4.2 The following documents will be needed to perform this procedure:

- Vendor Information Manuals listed in section 2.4

4.3 The following conditions must be met before this test may commence:

4.3.1 Verify the Pumping and Instrumentation Control Skid (PICS) has been set adjacent to the test area.

4.3.2 Ensure all PICS valves are CLOSED and all PICS breakers are OPEN prior to starting test.

4.3.3 Verify that the associated Jet Pump Jumper and Jumper test assembly have been placed in the pump run in pit or on a prepared test site.

4.3.4 Verify that the PICS water tank has been filled to capacity.

4.3.5 Verify the PICS has been grounded.

4.3.6 Verify that the Jet Pump Jumper has been connected to the PICS.

4.3.7 Test Director (WHC) shall walk down entire test area.

4.3.8 Test Director SHALL VERIFY that section 4.3 is complete by signing below.

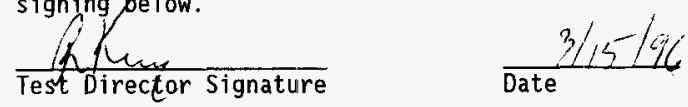

4.3.9 QC Inspector SHALL VERIFY that section 4.3 is complete by signing below.
$\frac{\text { Grovorz Mapa }}{\text { QC Inspector Signature }}$
$\frac{31.5196}{\text { Date }}$

0




\subsection{PROCEDURE}

\subsection{PICS ELECTRICAL AND PROCESS AIR POWER UP}

5.1.1 ENERGIZE the PICS by PERFORMING the following:

5.1.1.1 CLOSE the PICS main DISCONNECT SWITCH SALW-DS-902A, "MAIN DISCONNECT 480V 3PH".

5.1.1.2 CLOSE DISCONNECT SWITCH SALW-DS-903A

"SALW-DP-901A PNL 480V 3PH".

5.1.1.3 CLOSE DISCONNECT SWITCH SALW-DS-904A, "IA CMP PWR $480 \mathrm{~V} 3 \mathrm{PH} "$.

5.1.1.4 CLOSE DISCONNECT SWITCH SALW-DS-905A, "SALT WELL PMP PWR $480 \mathrm{~V} 3 \mathrm{PH}^{\prime \prime}$.

NOTE - Breakers in panelboard are arranged horizontally from left to right. The following circuit breakers are located in SALW-DP-901A "SALW SKID DIST PNL".

5.1.2 ENERGIZE PICS systems by PERFORMING the following:

5.1.2.1 CLOSE circuit breaker $1 \& 3$, "MAIN".

5.1.2.2 CLOSE Circuit Breaker 2, "WFIE POWER" \& "WFIE HEATER" .

5.1.2.3 CLOSE Circuit Breaker 8, "HEAT TRACE CAB".

5.1.2.4 CLOSE Circuit Breaker 6, "WATER TANK HEATER". 
5.1.2.5 CLOSE Circuit Breaker 7, "INSTR CAB".

5.1.2.6 CLOSE Circuit Breaker 4, "AIR CAB"

5.1.3 OPEN valve SALW-V-934A (located in the Instrument Air Enclosure).

5.1.4 START air compressor SALW-CMP-901A "SALW SKID IA COMP" by POSITIONING the switch to the HAND position.

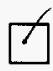

NOTE - Air Compressor should kick off at 90 psi ( \pm 4 psig).

5.1.5 VERIFY that Air Compressor starts and builds up pressure as INDICATED by pressure gauge SALW-PI-907A "AIR DRYER OUTLET PRESS".

5.1.6 VALVE in air to the PICS Water Tank by SLOWLY PERFORMING the following (Refer to Figure 1):

5.1.6.1 SLOWLY OPEN valve SALW-V-925A (7ocated in SALW-PNL-801H "INST AIR COMP ENCL'").

5.1.6.2 SLOWLY OPEN valve SALW-V-927A (located near the instrument water tank).

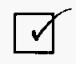

5.1.6.3 SLOWLY OPEN valve SALW-V-928A (1ocated near the instrument water tank).

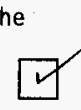

5.1.6.4 ADJUST PRV SALW-PCV-906A to $30 \mathrm{psi}( \pm 3 \mathrm{psig}$ ) as INDICATED by pressure gauge SALW-PI-908A "IA PRESS TO WTR TNK".

\begin{tabular}{|c|l|lc|}
\hline $\begin{array}{l}\text { Document No. } \\
\text { WHC-SD-WM-ATR-171 }\end{array}$ & Rev/Mod & 0 & 18 \\
\hline
\end{tabular}


NOTE - If Diptubes are not installed in test area, process air and drip water will be expelled from the side of SALW-PNL-902A "LEVEL INST ENCL". Attach temporary portable hose from diptube outlet to high and medium diptubes in the side of the weight factor enclosure, (from valves SALW-V-905A and $S A(W-V-907 A)$. Route the flexible hose to a suitable drain and secure.

5.1.7 VALVE IN air to SALW-PNL-902A "LEVEL INST ENCL" by PERFORMING the following (Refer to Figure 1 and 2):

5.1.7.1 SLOWLY OPEN valve SALW-V-926A (located in SALW-PNL-901A "INST AIR COMP ENCL").

5.1.7.2 SLOWLY OPEN valve SALW-V-901A (located in the bottom of SALW-PNL-902A "LEVEL INST ENCL").

5.1.7.3 ADJUST pressure control valve SALW-PCV-901A in SALW-PNL-902A "LEVEL INST ENCL" to 20 psi $( \pm 2$ psi) as INDICATED by the pressure gauge located on the face of the valve.

5.1.7.4 SLOWLY OPEN valve SALW-V-904A (located in the middle of SALW-PNL-902A "LEVEL INST ENCL").

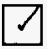

5.1.7.5 SLOWLY OPEN valve SALW-V-903A located in the middle of SALW-PNL-902A "LEVEL INST ENCL").

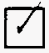

5.1.7.6 SLOWLY OPEN valve SALW-V-905A (located in the bottom left of SALW-PNL-902A "LEVEL INST ENCL").

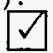

5.1.7.7 SLOWLY OPEN valve SALW-V-906A (located in the bottom left of SALW-PNL-902A "LEVEL INST ENCL").

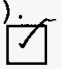

5.1.7.8 SLOWLY OPEN Valve SALW-V-907A (located in the bottom left of SALW-PNL-902A "LEVEL INST ENCL"). 
5.1.7.9 SLOWLY OPEN valve SALW-V-902A (10cated in the bottom left of SALW-PNL-902A "LEVEL INST ENCL").

5.1.7.10 SLOWLY OPEN valve SALW-V-920A (located in the middle left of SALW-PNL-902A "LEVEL INST ENCL")

5.1.7.11 SLOWLY OPEN valve SALW-V-921A (located in the middle left of SALW-PNL-902A "LEVEL INST ENCL").

5.1.7.12 SLOWLY OPEN valve SALW-V-919A (located in the middle left of SALW-PNL-902A "LEVEL INST ENCL")

5.1.8 ADJUST the air flow through the diptubes by PERFORMING the following:

5.1.8.1 ADJUST SALW-PDCV-902A "IA REG TO FIV-902A" (10cated in the top of SALW-PNL-902A "LEVEL INST ENCL") to APPROXIMATELY I.5 CFH ( $\pm 0.5 \mathrm{CFH})$ as INDICATED by SALW-FIV-902A.

$$
\text { Th s/sich }
$$

5.1.8.2 ADJUST SALW-PDCV-903A "IA REG TO FIV-903H" A (located in the top of SALW-PNL-902A "LEVEL INST ENCL") to APPROXIMATELY $1.5 \mathrm{CFH}( \pm 0.5 \mathrm{CFH})$ as INDICATED by SALW-FIV-903A.

$$
m_{\text {Tw/s/96 }}^{3 / 4}
$$

5.1.8.3 ADJUST SALW-PDCV-904A "IA REG TO FIV-904H" A (located in the top of SALW-PNL-902A "LEVEL INST ENCL") to APPROXIMATELY $1.5 \mathrm{CFH}( \pm 0.5 \mathrm{CFH})$ as INDICATED by SALW-FIV-904A.

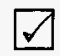

5.1.9 CONFIRM that a signal is present between the WFIE Instruments and the PLC by PERFORMING the following:

5.1.9.1 VERIFY Weight Factor is approximately $0.0^{\prime \prime} \mathrm{wg}$ as INDICATED by DTAM. 
5.1.9.2 Verify Specific Gravity is approximately $0.0^{\prime \prime} \mathrm{Wg}$ as INDICATED by DTAM.

5.1.9.3 VERIFY Flow rate is approximately $0.0 \mathrm{GPM}$ as INDICATED by DTAM.

5.1.10 Test Director SHALL VERIFY that section 5.1 is complete by signing below.
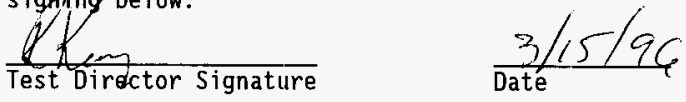

5.1.11 QC Inspector SHALL VERIFY that section 5.1 is complete by signing below.

$\frac{\text { Erowse } M A T A}{\text { QC Inspector Signature }}$

$\frac{31.5 / 96}{\text { Date }}$




\subsection{PICS WATER DRIP SYSTEM}

NOTE - If Diptubes are not installed in test area, process air and drip water will be expelled from the side of the WFIE. Attach temporary portable hose from diptube outlet to high and medium diptubes in the bottom of the weight factor enclosure, (from valves SALW-V-905A and SALW-V-907A). Route the flexible hose to a suitable drain and secure.

NOTE - When adjusting pressure regulator SALW-PCV-905A, be careful not to APPROACH 25 psig or the SALW-PRV-901A relief valve will actuate and relieve the pressure.

5.2.1 ACTUATE in the Dip Tube Drip system by PERFORMING the following:

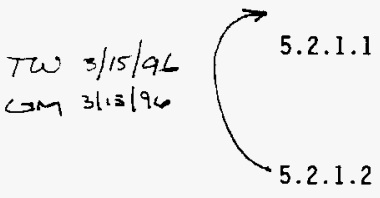

.1 .2

5.2 .1 .3
SLOWLY OPEN valve SALW-V-918A (located in the bottom right of SALW-PNL-902A "LEVEL INST ENCL").

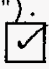

SLOWLY OPEN valve SALW-V-916A (located in the middle of SALW-PNL-902A "LEVEL INST ENCL").

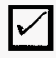

ADJUST Pressure Regulator SALW-PCV-905A, located in the bottom of SALW-PNL-902A "LEVEL INST ENCL", to 20 psi ( \pm 2 psig) as INDICATED by SALW-PI-90IA in the middle of the WFIE.

5.2.1.4 SLOWLY OPEN valve SALW-V-913A (located in the middle of SALW-PNL-902A "LEVEL INST ENCL") .

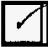

5.2.1.5 SLOWLY OPEN valve SALW-V-908A (located in the middle of SALW-PNL-902A "LEVEL INST ENCL").

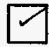

5.2.1.6 SLOWLY OPEN valve SALW-V-915A (located in the middle of SALW-PNL-902A "LEVEL INST ENCL"). 
5.2.1.7 SLOWLY OPEN valve SALW-V-914A (located in the middle of SALW-PNL-902A "LEVEL INST ENCL").

5.2.1.8 ADJUST valve SALW-V-914A to a llow APPROXIMATELY 2 drops/second ( \pm 1 drop/second) as INDICATED by sight glass SALW-FG-901A "SW TO LS SGT SEN LINE"

5.2.1.9 ADJUST valve SALW-V-915A to allow APPROXIMATELY 2 drops/second ( $\pm 1 \mathrm{drop} / \mathrm{second}$ ) as INDICATED by sight glass SALW-FG-902A "SW FLOW TO HS SGT/LT SEN LINE".

NOTE - Instrument air to the DOV will remain valved in for testing in subsequent steps.

5.2.2 VALVE OUT the Diptube purge air and drip water by PERFORMING the following:

5.2.2.1 SLOWLY CLOSE valve SALW-V-925A (located in SALW-PNL-901A "INST AIR COMP ENCL").

5.2.2.2 SLOWLY CLOSE valve SALW-V-927A (located near the inside top of SALW-PNL-903A "WATER TANK ENCL")

5.2.2.3 SLOWLY CLOSE valve SALW-V-928A (1ocated near the inside top of SALW-PNL-903A "WATER TANK ENCL")

5.2.2.4 SLOWLY CLOSE valve SALW-V-918A located in the bottom of SALW-PNL-902A "LEVEL INST ENCL").

5.2.2.5 SLOWLY CLOSE VaTve SALW-V-916A located in the middle of SALW-PNL-902A "LEVEL INST ENCL").

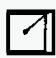

5.2.2.6 SLOWLY CLOSE valve SALW-V-915A (located in the middle of SALW-PNL-902A "LEVEL INST ENCL"). 


\subsection{PICS WATER DRIP SYSTEM (continued)}

5.2.2.7 SLOWLY CLOSE valve SALW-V-914A (1ocated in the middle of SALW-PNL-902A "LEVEL INST ENCL").

5.2.2.8 SLOWLY CLOSE valve SALW-V-913A (1ocated in the middle of SALW-PNL-902A "LEVEL INST ENCL").

5.2.2.9 SLOWLY CLOSE VaIve SALW-V-908A (located in the middle of SALW-PNL-902A "LEVEL INST ENCL").

5.2.2.10 SLOWLY CLOSE VaTve SALW-V-906A (located in the bottom of SALW-PNL-902A "LEVEL INST ENCL").

5.2.2.11 SLOWLY CLOSE valve SALW-V-905A (located in the bottom of SALW-PNL-902A "LEVEL INST ENCL").

\subsubsection{SLOWLY CLOSE vaTve SALW-V-907A Tocated in the} bottom of SALW-PNL-902A "LEVEL INST ENCL").

5.2.3 Test Director SHALL VERIFY that section $\mathbf{5 . 2}$ is complete by signing below.
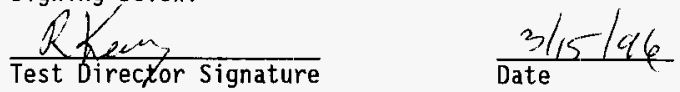

5.2.4 QC Inspector SHALL VERIFY that section 5.2 is complete by signing below.

$\frac{\text { caceus mata }}{\text { QC Inspector Signature }}$

$$
\frac{31.5196}{\text { Date }}
$$

0




\subsection{WEIGHT FACTOR AND SPECIFIC GRAVITY SYSTEM}

NOTE - The test manometer will read the pressure as seen by the WFI or SGI.

5.3.1 CONNECT the 0-500" wg test Manometer pressure source to the HIGH PRESSURE INLET side of the WFI (1 abeled as SALW-LT-902A "SALT WELL LEVEL XMITTER").

5.3.2 ENSURE the WFI (1 abeled as SALW-LT-902A "SALT WELL LEVEL

XMITTER") LOW PRESSURE SIDE is OPEN to the atmosphere.

5.3.3 CLOSE the WFI (1abeled as SALW-LT-902A "SALT WELL LEVEL

XMITTER") equalizing valve.

5.3.4 CONNECT the $0-20 "$ wg test Manometer pressure source to the HIGH PRESSURE INLET side of the SGI (labeled as SALW-SGT-80IH "SP GRAV XMITTER").

5.3.5 ENSURE the SGI (1 abeled as SALW-SGT-801H "SP GRAV XMITTER")

LOW PRESSURE SIDE is OPEN to the atmosphere.

5.3.6 CLOSE the SGI (labeled as SALW-SGT-801H "SP GRAV XMITTER")

equalizing valve.

5.3.7 SET the WFI test Manometer to $0 "$ wg.

5.3.8 SET the SGI test Manometer to 0" wg.

1




\subsection{WEIGHT FACTOR AND SPECIFIC GRAVITY SYSTEM (cont inued)}

5.3.9 OBSERVE the DTAM AND RECORD the Weight Factor and Specific Gravity readings on the table below.

\begin{tabular}{|c|c|}
\hline $\begin{array}{c}\text { WEIGHT FACTOR READING } \\
\text { (RANGE } 0 \pm 10 \text { in } \mathrm{Wg} \text { ) }\end{array}$ & $\begin{array}{c}\text { SPECIFIC GRAVITY READING } \\
\text { (RANGE } 0 \pm 0.1 \text { in wg) }\end{array}$ \\
\hline 0 & .05 \\
\hline
\end{tabular}

5.3.10 SET the WFI test Manometer to $125^{\prime \prime} \mathrm{wg}$.

5.3.11 SET the SGI test Manometer to 5" wg.

5.3.12 OBSERVE the DTAM AND RECORD the Weight Factor and Specific Gravity readings on the table below.

\begin{tabular}{|c|c|}
\hline $\begin{array}{l}\text { WEIGHT FACTOR READING } \\
\text { (RANGE 125 } \pm 10 \text { in } \mathrm{Wg} \text { ) }\end{array}$ & $\begin{array}{c}\text { SPECIFIC GRAVITY READING } \\
\text { (RANGE } 5 \pm 0.1 \text { in Wg) }\end{array}$ \\
\hline 125 & 5.08 \\
\hline
\end{tabular}

5.3.13 SET the WFI test Manometer to $250^{\prime \prime} \mathrm{wg}$.

5.3.14 SET the SGI test Manometer to $10^{\prime \prime} \mathrm{wg}$.

5.3.15 OBSERVE the DTAM AND RECORD the Weight Factor and Specific Gravity readings on the table below.

\begin{tabular}{|c|c|}
\hline $\begin{array}{c}\text { WEIGHT FACTOR READING } \\
\text { (RANGE 250 } \pm 10 \text { in Wg) }\end{array}$ & $\begin{array}{l}\text { SPECIFIC GRAVITY READING } \\
\text { (RANGE 10 } \pm 0.1 \text { in Wg) }\end{array}$ \\
\hline 250.1 & 10.08 \\
\hline
\end{tabular}




\subsection{WEIGHT FACTOR AND SPECIFIC GRAVITY SYSTEM (continued)}

5.3.16 SET the WFI test Manometer to $375^{\prime \prime} \mathrm{wg}$.

5.3.17 SET the SGI test Manometer to $15^{\mathrm{N}} \mathrm{wg}$.

5.3.18 OBSERVE the DTAM AND RECORD the Weight Factor and Specific Gravity readings on the table below.

\begin{tabular}{|c|c|}
\hline $\begin{array}{c}\text { WEIGHT FACTOR READING } \\
\text { (RANGE } 375 \pm 10 \text { in wg) }\end{array}$ & $\begin{array}{c}\text { SPECIFIC GRAVITY READING } \\
\text { (RANGE 15 } \pm 0.1 \text { in wg) }\end{array}$ \\
\hline 375.1 & $15.0 \%$ \\
\hline
\end{tabular}

5.3.19 SET the WFI test Manometer to 500" wg.

5.3.20 SET the SGI test Manometer to 20" wg.

5.3.21 OBSERVE the DTAM AND RECORD the Weight Factor and Specific Gravity readings on the table below.

\begin{tabular}{|c|c|}
\hline $\begin{array}{c}\text { WEIGHT FACTOR READING } \\
\text { (RANGE } 500 \pm 10 \text { in Wg) }\end{array}$ & $\begin{array}{c}\text { SPECIFIC GRAVITY READING } \\
\text { (RANGE 20 } \pm 0.1 \text { in Wg) }\end{array}$ \\
\hline $500.5 \% 2$ & 20 \\
\hline
\end{tabular}

NOTE - The SGI (labeled as SALW-SGT-801H "SP GRAV XMITTER") test manometer will need to remain hooked up for subsequent test steps.

5.3.22 DISCONNECT the $0-500^{\prime \prime}$ test Manometer pressure source from the HIGH PRESSURE INLET side of the WFI (1abeled as SALW-LT-902A "SALT WELL LEVEL XMITTER"). 


\subsection{WEIGHT FACTOR AND SPECIFIC GRAVITY SYSTEM (cont inued)}

5.3.23 ISOLATE the WFI (1abeled as SALW-LT-902A "SALT WELL LEVEL XMITTER") by OPENING the WFI equalizing valve AND CLOSING the two (2) isolation valves (a11 three valves are located on the three valve manifold SALW-V-936A "I.T-902A 3-VLV MANIF").

5.3.24 Test Director SHALL VERIFY that section 5.3 is complete by signing below.
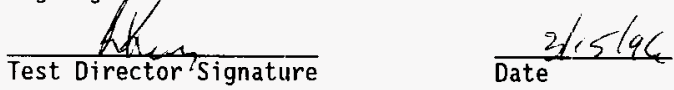

5.3.25 QC Inspector SHALL VERIFY that section 5.3 is complete by signing below.

$\frac{\text { Coowere MASA }}{\text { QC Inspector Signature }} \frac{31.5196}{\text { Date }}$

0




\subsection{DOV AUTOMATIC AND MANUAL OPERATION}

NOTE - This system is a Proportional Integral Derivative (PID) controller for controlling the liquid level in the sattwell screen. The SGI reads unadjusted liquid level once the middle diptube leg is uncovered by declining liquid levels. The system uses the signal from the SGI as the Process Variable. The controller compares the process variable to the setpoint and adjusts the DOV position accordingly (manipulated variable). The purpose of this test section is to verify that the DOV trend is toward achieving the setpoint while different process variables are simulated.

5.4.1 ENSURE the Saltwell Jumper and PICS is CONFIGURED for AUTOMATIC DOV level control by PERFORMING the following (Refer to Figures 3 and 4 ):

5.4.1.1 SET the SGI test Manometer to a pressure of $0 "$ wg.

5.4.1.2 SET the PID loop setpoint to seven (7) inches USING the DTAM.

5.4.1.3 ENSURE that only alarms "A1 arm 12 JET PUMP SHUTDOWN" and "Alarm 13 SGT LOW" DTAM are DISPLAYED on the DTAM.

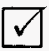

5.4.1.4 PLACE the saltwell jumper JR-1 valve in the PROCESS position.

5.4.1.5 ENSURE pump recirculation apparatus is filled

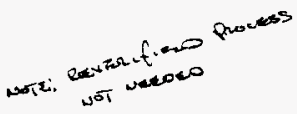

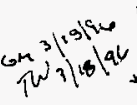
through the saltwell Jet pump.

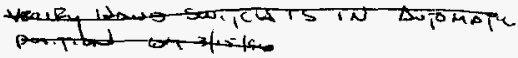

5.4.1.6 START the Jet pump USING the DTAM.

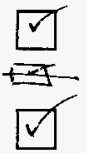

5.4.1.7 SET the SGI test Manometer to a pressure of $20^{\prime \prime}$ wg. 


\subsection{DOV AUTOMATIC AND MANUAL OPERATION (continued)}

5.4.1.8 PLACE the PID in the AUTO position USING the DTAM.

5.4.1.9 VERIFY that the DOV moves to a more OPEN position.

5.4.1.10 SET the SGI test Manometer to a pressure of 4 " wg.

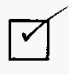
5.4.1.11 VERIFY that the DOV moves to a more CLOSED
position.

5.4.2 VERIFY that the Saltwell Low Level alarm is functional by PERFORMING the following steps:

5.4.2.1 SET the SGI test Manometer to a pressure of 15" wg.

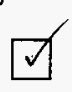

5.4.2.2 VERIFY that the DOV is NOT FULLY CLOSED (DOV should be open somewhat to try to achieve the setpoint).

5.4.2.3 VERY SLOWLY DECREASE the SGI test Manometer pressure.

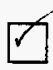

5.4.3 WHEN the SGI LOW (alarm 13 at DTAM) alarm has ANNUNCIATED, RECORD the following:

\begin{tabular}{|c|c|c|}
\hline $\begin{array}{c}\text { SGI MANOMETER } \\
\text { READING } \\
\text { (RANGE } 3.5 \pm 1.0 \text { in } \\
\text { Wg) }\end{array}$ & $\begin{array}{c}\text { DOV POSITION } \\
\text { (\% OPEN) } \\
\text { [RANGE - FULLY } \\
\text { CLOSED] }\end{array}$ & $\begin{array}{c}\text { SALW-PI-905A } \\
\text { PRESSURE } \\
\text { (RANGE 3 } \pm 1.0 \\
\text { PSIg) }\end{array}$ \\
\hline 3.41 & CLOSRD & $?$ \\
\hline
\end{tabular}

0


5.4 DOV aUtOMATIC AND MaNUAL OPERATION (Continued)

5.4.4 VERIFY that the DTAM DISPLAYS "Alarm 13 SGI LOW".

5.4.3 VERIFY that the MANUAL CONTROL of the DOV is operational by PERFORMING the following steps:

5.4.4.1 SET the SGI test Manometer to a pressure of $15^{\text {f }}$ wg.

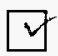

5.4.4.2 SET the PID loop to MANUAL CONTROL USING the DTAM.

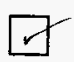

5.4.4.3 SET the DOV to $0 \%$ Open USING the manual control on the DTAM.

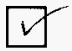

5.4.5 RECORD the following:

\begin{tabular}{|c|c|}
\hline $\begin{array}{c}\text { DOV POSITION } \\
\text { (\% OPEN) } \\
\text { [RANGE - FULLY } \\
\text { CLOSED] }\end{array}$ & $\begin{array}{c}\text { SALH-PI-905A } \\
\text { PRESSURE }\end{array}$ \\
(RANGE $3 \pm 1.0$ psig) \\
\hline CLOSEO & 3 \\
\hline
\end{tabular}

5.4.6 SET the DOV to $25 \%$ OPEN USING the manual control on the DTAM.

5.4.7 RECORD the following:

\begin{tabular}{|c|c|}
\hline $\begin{array}{c}\text { DOV POSITION } \\
(\% \text { OPEN) }\end{array}$ & $\begin{array}{c}\text { SALW-PI-905A } \\
\text { PRESSURE } \\
\text { [RANGE: } 25 \% \pm 10 \%]\end{array}$ \\
(RANGE: $6 \pm 1.0$ \\
PSig)
\end{tabular}


5.4 DOV aUtOMATIC AND manual OPERATION (Continued)

5.4.8 SET the DOV to 75\% OPEN USING the manual control on the DTAM.

5.4.9 RECORD the following:

\begin{tabular}{|c|c|}
\hline $\begin{array}{c}\text { DOV POSITION } \\
\text { (\% OPEN) } \\
\text { [RANGE: 75\% } \pm 10 \%]\end{array}$ & $\begin{array}{c}\text { SALL-PI-905A } \\
\text { PRESSURE } \\
\text { (RANGE: 12 } \pm 1.0 \\
\text { PSig) }\end{array}$ \\
\hline $75 \% 0$ & 12 \\
\hline
\end{tabular}

5.4.10 SET the DOV to 100\% OPEN USING the manual control on the DTAM.

5.4.11 RECORD the following:

\begin{tabular}{|c|c|}
\hline $\begin{array}{c}\text { DOV POSITION } \\
\text { (\% OPEN) } \\
\text { [RANGE: } 100 \% \pm 10 \%]\end{array}$ & $\begin{array}{c}\text { SALW-PI-905A } \\
\text { PRESSURE }\end{array}$ \\
RANGE: $15 \pm 1.0 \mathrm{psig}$ \\
\hline $100 \%$
\end{tabular}

5.4.12 VERY SLOWLY DECREASE the SGI test Manometer pressure while OBSERVING the DOV.

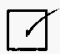

5.4.13 VERIFY that the DOV REMAINS FULLY OPEN while the SGI Manometer is DECREASED UNTIL the "SGI LOW" alarm (DTAM al arm 13) ANNUNCIATES.

5.4.14 VERIFY that the DOV IMMEDIATELY CLOSES WHEN the "SGI LOW" a larm (DTAM a 7 arm 13) ANNUNCIATES. 


\section{TANK FARM ACCEPTANCE TEST PROCEDURE}

5.4 doV automatic and manual operation (Continued)

5.4.15 SHUTDOWN the Jet pump with the DTAM.

5.4.16 Test Director SHALL VERIFY that section 5.4 is complete by signing below.

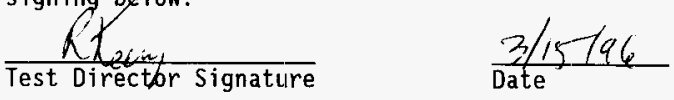

5.4.17 QC Inspector SHALL VERIFY that section 5.4 is complete by signing below.
$\frac{\text { Gizozoz MATA }}{\text { QC Inspector Signature }}$
$\frac{3 \text { is } 196}{\text { Date }}$ 


\subsection{JET PUMP FLOWMETER OPERATION}

5.5.1 ENSURE that the Saltwell Jumper Flow Element is communicating properly with the FQIT and DTAM by PERFORMING the following:

5.5.1.1 PLACE the saltwell jumper JR-1 valve in the PROCESS position.

5.5.1.2 ENSURE Pump recirculation apparatus is filled with water AND CONFIGURED to circulate water through the saltwell Jet pump.

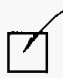

5.5.1.3 ENSURE test manometer is still attached to the SGI AND SET to $15^{\prime \prime} \mathrm{Wg}$.

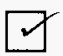

5.5.1.4 ENSURE a rotameter has been installed in series with the jumper flow element as part of the Jumper Test Assembly (see Figures 3 and 4 ).

5.5.1.5 SET the DOV to 0\% Open USING the manual control on the DTAM.

5.5.1.6 ENSURE Jet pump Jumper Valve JR-2 is CLOSED.

5.5.1.7 START the Jet pump USING the DTAM.

5.5.1.8 SET the manual DOV control to OBTAIN a flowrate of APPROXIMATELY $1 \mathrm{GPM}$ through the jumper.

5.5.1.9 VERIFY a flowrate of APPROXIMATELY 1 GPM through the jumper is INDICATED by the test flowmeter. 


\section{TANK FARM ACCEPTANCE TEST PROCEDURE}

\begin{tabular}{|c|c|c|c|c|}
\hline 5.5 .2 & \multicolumn{2}{|c|}{ RECORD the following: } & \multicolumn{2}{|c|}{$\begin{array}{l}\text { जi } 3 / 15196 \\
7203 / 15 / 96 \\
\text { * Bnooks }\end{array}$} \\
\hline $\begin{array}{c}\text { DTAM } \\
\text { MANUAL } \\
\text { CONTROL } \\
\text { DOV } \\
\text { POSITION } \\
(\%)\end{array}$ & $\begin{array}{l}\text { DOV POSITION } \\
\text { (\% OPEN) }\end{array}$ & $\begin{array}{c}\text { TEST } \\
\text { FLOWHETER } \\
\text { FLOWRATE } \\
\text { (GPM) }\end{array}$ & $\begin{array}{l}\text { JOHWSON } \\
\text { YOKOGAWH } \\
\text { FQIT } \\
\text { FLOWRATE } \\
\text { (GPM) }\end{array}$ & $\begin{array}{l}\text { DTAM } \\
\text { FLOWRATE } \\
\text { (GPM) }\end{array}$ \\
\hline 35020 & 6090 & 1 & .96 & 95 \\
\hline
\end{tabular}

5.5.3 VERIFY that Test Flowmeter flowrate and FQIT flowrate are WITHIN $\pm 0.4 \mathrm{GPM}$

5.5.4 VERIFY that the DTAM flowrate (from the FQIT) and Kogawa FQIT flowrate are WITHIN \pm 0.4 GPM.

5.5.5 SET the manual DOV control to OBTAIN a flowrate of APPROXIMATELY $2.5 \mathrm{GPM}$ through the jumper.

5.5.6 VERIFY a f] owrate of APPROXIMATELY $2.5 \mathrm{GPM}$ through the jumper is INDICATED by the test flowmeter.

\subsubsection{RECORD the following:}

\begin{tabular}{|c|c|c|c|c|}
\hline $\begin{array}{l}\text { DTAM } \\
\text { MANUAL } \\
\text { CONTROL } \\
\text { DOV } \\
\text { POSITION } \\
(\%)\end{array}$ & $\begin{array}{l}\text { DOV POSITION } \\
\text { (\% OPEN) }\end{array}$ & $\begin{array}{l}\text { TEST } \\
\text { FLOWHETER } \\
\text { FLOWRATE } \\
\text { (GPM) }\end{array}$ & $\begin{array}{l}\text { * } \\
\text { JOAMSOH } \\
\text { YOKOGALA } \\
\text { FQIT } \\
\text { FLOWRATE } \\
\text { (GPH) }\end{array}$ & $\begin{array}{l}\text { DTAM } \\
\text { FLOWRATE } \\
\text { (GPM) }\end{array}$ \\
\hline $\begin{array}{l}9090 \\
2=-3-\end{array}$ & 9590 & 2.5 & 2.52 & $2=3$ \\
\hline
\end{tabular}




\subsection{JET PUMP FLOWMETER OPERATION (continued)}

5.5.8 VERIFY that Test Flowmeter flowrate and dohnson Yokogata FQIT flowrate are WITHIN $\pm 0.4 \mathrm{GPM}$

5.5.9 VERIFY that the DTAM flowrate (from the FQIT) and Fog flowrate are WITHIN $\pm 0.4 \mathrm{GPM}$.

NOTE - If $4.0 \mathrm{gpm}$ is not obtainable, open DOV fully (100\%).

5.5.10 SET the manual DOV control to OBTAIN a flowrate of APPROXIMATELY 4.0 GPM through the jumper.

5.5.11 VERIFY a flowrate of APPROXIMATELY $4.0 \mathrm{GPM}$ through the jumper is INDICATED by the test flowmeter.

5.5.12 RECORD the following:

\begin{tabular}{|c|c|c|c|c|}
\hline $\begin{array}{l}\text { DTAM } \\
\text { MANUAL } \\
\text { CONTROL } \\
\text { DOV } \\
\text { POSITION } \\
(\%)\end{array}$ & $\begin{array}{l}\text { DOV POSITION } \\
\text { (\% OPEN) }\end{array}$ & $\begin{array}{l}\text { TEST } \\
\text { FLOWHETER } \\
\text { FLONRATE } \\
\text { (GPM) }\end{array}$ & $\begin{array}{c}* \\
\text { JOHISON } \\
\text { YOKOGHWA } \\
\text { FQIT } \\
\text { FLOWRATE } \\
\text { (GPM) }\end{array}$ & $\begin{array}{l}\text { DTAM } \\
\text { FLOWRATE } \\
\text { (GPM) }\end{array}$ \\
\hline $100 \%$ & 10090 & 3.0 & 3.04 & 3.01 \\
\hline 5.5 .13 & \multicolumn{4}{|c|}{$\begin{array}{l}\text { VERIFY that Test Flowneter flowrate and Jomson Yokgat } \\
\text { FQIT flowrate are WITHIN } \pm 0.4 \mathrm{GPM}\end{array}$} \\
\hline
\end{tabular}

5.5.14 VERIFY that the DTAM flowrate (from the FQIT) and dohnson FQIT flowrate are WITHIN $\pm 0.4 \mathrm{GPM}$.

5.5.15 CLOSE the DOV (to 0\%) USING the manual DOV control. 


\subsection{JET PUMP FLOWMETER OPERATION (cont inued)}

5.5.16 RECORD the following:

\begin{tabular}{|c|c|c|c|c|}
\hline $\begin{array}{c}\text { DTAM } \\
\text { MANUAL } \\
\text { CONTROL } \\
\text { DOV } \\
\text { POSITION } \\
(\%)\end{array}$ & $\begin{array}{l}\text { DOV POSITION } \\
\text { (\% OPEN) }\end{array}$ & $\begin{array}{c}\text { TEST } \\
\text { FLOWWETER } \\
\text { FLOWRATE } \\
\text { (GPM) }\end{array}$ & $\begin{array}{c}* \\
\text { JOHISON } \\
\text { YOKOGAWH } \\
\text { FQIT } \\
\text { FLOWRATE } \\
\text { (GPH) }\end{array}$ & $\begin{array}{l}\text { DTAM } \\
\text { FLOWRATE } \\
\text { (GPM) }\end{array}$ \\
\hline 090 & $\angle L O A \overrightarrow{A C})$ & 2 & 0 & \\
\hline
\end{tabular}

5.5.17 VERIFY that Test Flowmeter flowrate and denfon flowrate are WITHIN $\pm 0.4 \mathrm{GPM}$

5.5.18 VERIFY that the DTAM flowrate (from the FQIT) and $*$ asop Hokogawa FQIT flowrate are WITHIN \pm 0.4 GPM.

5.5.19 REMOVE the test manometer from the SGI.

5.5.20 ISOLATE the SGI (labeled as SALW-SGT-801H "SP GRAV XMITTER") from the system by OPENING the equalization valve AND CLOSING the two (2) isolation valves (all three valves are located on the SGI three valve manifold SALW-V-935A "SGI-901A 3-VLV MANIF").

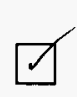

5.5.21 SHUTDOWN the Jet pump at the DTAM.

5.5.22 Test Director SHALL VERIFY that section 5.5 is complete by signing botow.

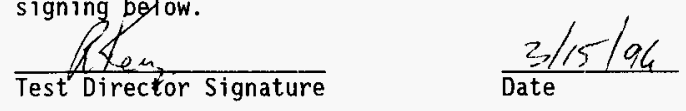

5.5.23 QC Inspector SHALL VERIFY that section 5.5 is complete by signing below.
$\frac{\text { Gronoz MaTA }}{\text { QC Inspector Signature }}$
$\frac{3 / 5196}{\text { Date }}$

Document No.

WHC-SD-WM-ATR-171

Rev/Mod 0




\subsection{WATER TANK LEVEL TRANSMITTER}
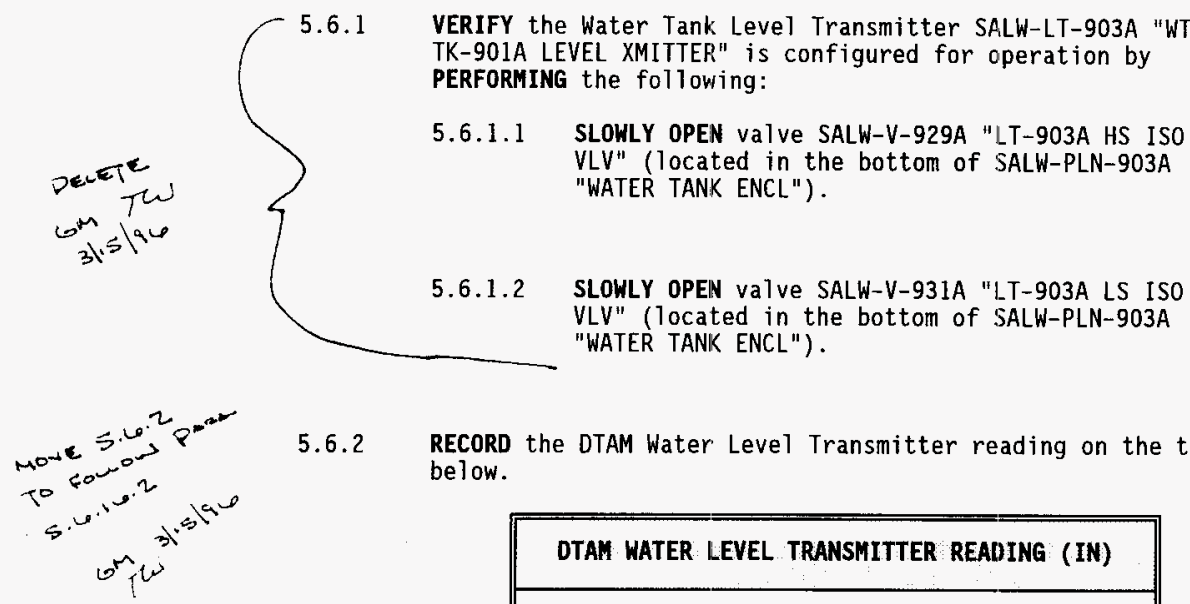

5.6 .2

RECORD the DTAM Water Level Transmitter reading on the table below.

DTAN WATER LEVEL TRANSMITTER READING (IN)

5.6.2 PREPARE the Water Tank Level Transmitter SALW-LT-903A "WTR TK-901A LEVEL XMITTER" for test signals by PERFORMING the following:

5.6.2.1 CLOSE valve SALW-V-929A "LT-903A HS ISO VLV"
(located in the bottom of SALW-PLN-903A "WATER
TANK ENCL").

5.6.2.2 CLOSE valve SALW-V-931A "LT-903A LS ISO VLV" (located in the bottom of SALW-PLN-903A "WATER TANK ENCL").

5.6.3 CONNECT a $0-50 "$ wg test Manometer pressure source to the HIGH PRESSURE vent/test port of the level transmitter SALW-LT-903A "WTR TK-901A LEVEL XMITTER" .

0


5.6.4 VERIFY the LOW PRESSURE vent/test port of the level transmitter SALW-LT-903A "WTR TK-901A LEVEL XMITTER" is OPEN to the atmosphere.

5.6.5 ADJUST the test manometer the SALW-LT-903A "WTR TK-90IA LEVEL XMITTER" to a pressure of $0^{\prime \prime} \mathrm{wg}$.

5.6.6 RECORD the following:

\begin{tabular}{|c|c|c|}
\hline $\begin{array}{c}\text { MANOMETER PRESSURE } \\
\text { (in Wg) }\end{array}$ & $\begin{array}{c}\text { DTAM WATER TANK } \\
\text { LEVEL } \\
\text { (RANGE: } 0 \pm 2.5 \\
\text { in) }\end{array}$ & $\begin{array}{c}\text { DTAN "PIN WATER } \\
\text { TANK LOW" ALARM } \\
\text { PRESENT } \\
(Y E S / N O)\end{array}$ \\
\hline 0 & 2 & YEs \\
\hline
\end{tabular}

5.6.7 ADJUST the test manometer on the SALW-LT-903A "WTR TK-901A LEVEL XMITTER" to a pressure of $25^{\prime \prime} \mathrm{wg}$.

5.6.8 RECORD the following:

\begin{tabular}{|c|c|c|}
\hline $\begin{array}{c}\text { MANOMETER PRESSURE } \\
\text { (in wg) }\end{array}$ & $\begin{array}{l}\text { DTAN WATER TANK } \\
\text { LEVEL } \\
\text { (RANGE: } 25 \pm 2.5 \\
\text { in) }\end{array}$ & $\begin{array}{l}\text { DTAM "PIN WATER TANK } \\
\text { LOW" ALARM PRESENT } \\
\text { (YES/NO) }\end{array}$ \\
\hline 25 & 25 & MO \\
\hline
\end{tabular}

5.6.9 ADJUST the test manometer on the SALW-LT-903A "WTR TK-901A LEVEL XMITTER" to a pressure of $50 " \mathrm{wg}$. 


\subsection{WATER TANK LEVEL TRANSMITTER (continued)}

5.6.10 RECORD the following:

\begin{tabular}{|c|c|}
\hline $\begin{array}{c}\text { MANOMETER PRESSURE } \\
\text { (in wg) }\end{array}$ & $\begin{array}{c}\text { DTAM WATER TANK } \\
\text { LEVEL } \\
\text { (RANGE: } 50 \pm 2.5 \text { in) }\end{array}$ \\
\hline $\mathrm{SC}$ & SC, \\
\hline
\end{tabular}

NOTE - Alarm 9 trips at 10 inches and resets at 12.5 inches.

5.6.11 VERIFY the PICS Water Tank Low Level Alarm (Alarm 9) is FUNCTIONAL by PERFORMING the following:

5.6.11.1 SLOWLY DECREASE the test manometer until the DTAM "Alarm 9 P $\| C$ Water Tank LOW" (Water Tank Low Level Alarn) ANNUNCIATES.

5.6.11.2 WHEN the Water Tank Low Level Alarm ANNUNCIATES, IMMEDIATELY RECORD the test manometer reading on the table below.

\begin{tabular}{|c|}
\hline $\begin{array}{l}\text { TEST MANOMETER READING } \\
\text { [RANGE: } 10 \pm 2 \text { in } \mathrm{Wg} \text { ] }\end{array}$ \\
\hline 8.05 \\
\hline
\end{tabular}

5.6.12 IF Alarm 9 DOES NOT ANNUNCIATE, RESET the trip setpoint and REPEAT all of step 5.6.11.

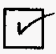

5.6.13 ADJUST the test manometer on the SALW-LT-903A "WTR TK-901A LEVEL XMITTER" to a pressure of $12.5^{\text {" }} \mathrm{wg}$.

0




\subsection{WATER TANK LEVEL TRANSMITTER (continued)}

5.6.14 RECORD the following:

\begin{tabular}{|c|c|c|}
\hline $\begin{array}{c}\text { MANOMETER PRESSURE } \\
\text { (in wg) }\end{array}$ & $\begin{array}{c}\text { DTAM WATER TANK } \\
\text { LEVEL } \\
\text { (RAMGE: } 12.5 \pm \\
2.5 \text { in) }\end{array}$ & $\begin{array}{c}\text { DTAM "PIN WATER TANK } \\
\text { LOW" ALARM PRESENT } \\
\text { (YES/NO) }\end{array}$ \\
\hline 11.36 & 12 & $N O$ \\
\hline
\end{tabular}

5.6.15 REMOVE the test manometer from the SALW-LT-903A "WTR TK-901A LEVEL XMITTER" HIGH PRESSURE vent/test port.

5.6.16 RESTORE the Water Tank Level Transmitter SALW-LT-903A "WTR TK-901A LEVEL XMITTER" for test signals by PERFORMING the following:

5.6.16.1 OPEN valve SALW-V-929A "LT-903A HS ISO VLV" (located in the bottom of the water tank enclosure).

5.6.17 Test Direftor SHALL VERIFY that section 5.6 is complete by

5.6.16.2 OPEN valve SALW-V-931A "LT-903A LS ISO VLV" (located in the bottom of the water tank enclosure).

$$
\text { S.L. } 2
$$
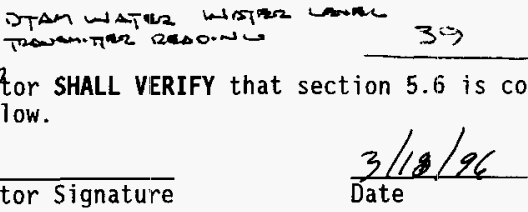

5.6.18 QC Inspector SHALL VERIFY that section 5.6 is complete by signing below.

$$
\frac{C+0}{\text { QC Inspector Signature }} \frac{3 / 106}{\text { Date }}
$$

WHC-SD-WM-ATR-171 


\subsection{JET PUMP HEAT TRACE AND INSTRUMENT TEMPERATURE}

5.7.1 CONNECT the $120 \mathrm{~V}$ switched input to terminals 7 through 14 of the phoenix connector (located in the Interconnect

Enclosure).

5.7.2 USING the DTAM, TURN ON the heat trace for the jet pump jumper.

5.7.3 VERIFY that the appropriate $120 \mathrm{~V}$ switched input indicator light is ILLUMINATED.

5.7.4 USING the DTAM, TURN ON the heat trace for the dip tubes.

5.7.5 VERIFY that the appropriate $120 \mathrm{~V}$ switched input indicator light is ILLUMINATED.

5.7.6 USING the DTAM, TURN OFF the heat trace for the jet pump jumper.

$$
\text { umper. }
$$

5.7.7 VERIFY that the appropriate $120 \mathrm{~V}$ switched input indicator light is NOT ILLUMINATED.

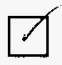

5.7.8 USING the DTAM, TURN OFF the heat trace for the dip tubes.

5.7.9 VERIFY that the appropriate $120 \mathrm{~V}$ switched input indicator

light is NOT ILLUMINATED.

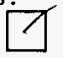

5.7.10 USING the DTAM, TURN ON the heat trace for the jet pump
jumper.
5.7 .11 USING the DTAM, TURN ON the heat trace for the dip tubes.

5.7.10 USING the DTAM, TURN ON the heat trace for the jet pump
jumper.
5.7 .11 USING the DTAM, TURN ON the heat trace for the dip tubes.
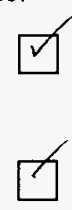

5.7 .11 USING the DTAM, TURN ON the heat trace for the dip tubes.

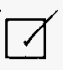

0


5.7.12 Test Director SHALL VERIFY that section 5.7 is complete by signing below.
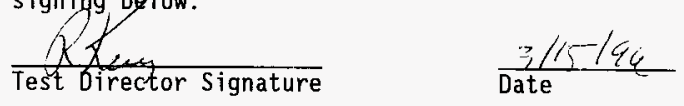

5.7.13 OC Inspector SHALL VERIFY that section 5.7 is complete by signing beTow.

$\frac{\text { GroweE MWIA }}{\text { QC Inspector Signature }}$

$\frac{3,15 / 56}{\text { Date }}$ 


\subsection{INTERLOCKS}

5.8.1 PLACE the saltwell jumper JR-I valve in the PROCESS position.

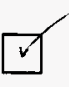

5.8.2 ENSURE the pump recirculation apparatus is filled with water AND CONFIGURED to circulate water through the saltwell Jet pump.

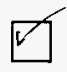

5.8.3 VERIFY no DTAM alarms are PRESENT with the exception of alarms 12 \& 13 .

5.8.4 START the Jet pump USING the DTAM.

\section{WARNING}

Energized circuits and leads are contained inside the cabinet. Observe appropriate electrical precautions.

5.8.5 ENSURE the 120V switched input is STILL connected to terminals 7 through 14 of the phoenix connector (1ocated in the Interconnect Enclosure).

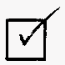

5.8.6 SIMULATE a FGM \#1 alarm condition by TOGGLING AND HOLDING the corresponding $120 \mathrm{~V}$ switched input switch.

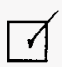

5.8.7 VERIFY light is NOT ILLUMINATED on PLC module 5 input 6 (the FGM-1 input) located in the Interconnect Enclosure).

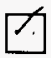

5.8.8 VERIFY strobe is FLASHING.

5.8.9 VERIFY horn is SOUNDING.

Rev/Mod 0


5.8.10 VERIFY jet pump is SHUTDOWN.

5.8.11 USING the DTAM, VERIFY the heat trace for the jet pump jumper is OFF.

5.8.12 USING the DTAM, VERIFY the heat trace for the dip tubes is OFF.

5.8.13 VERIFY "Alarm 12 JET PUMP SHUTDOWN" is DISPLAYED on the DTAM.

5.8.14 ACKNOWLEDGE the alarm by PRESSING "Y".

5.8.15 VERIFY strobe is NOT FLASHING.

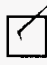

5.8.16 ACKNOWLEDGE the alarm by PRESSING " $Y$ ".

5.8.17 VERIFY "Alarm 18 Saltwell FGM HIGH" is STILL DISPLAYED on the DTAM.

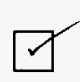

5.8.18 USING the DTAM's Main Menu, VERIFY "Alarm 12 JET PUMP SHUTDOWN" and "Alarm 18 Saltwell FGM HIGH" are displayed as IN ALARM.

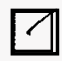

5.8.19 RELEASE the corresponding FGM \#1 $120 \mathrm{~V}$ switched input switch.

$$
\text { Tuan ous Tw } 3 / 18 / 96
$$

5.8.20 USING the DTAM, VERIFY the heat trace for the jet pump. jur int.

$$
\text { Tuon on Tw 3/18/96 }
$$

5.8.21 USING the DTAM, WERIF the heat trace for the dip tubes. is ON.

0




\subsection{INTERLOCKS (continued)} 5.8.22 USING the DTAM's Main Menu, VERIFY "Alarm 18 Saltwell FGM
HIGH" has CLEARED.

NOTE - When the jet pump is restarted the "Alarm 12 JET PUMP SHUTDOWN" will automatically clear.

5.8.23 RESTART the Jet pump USING the DTAM.

5.8.24 SIMULATE a FGM \#2 alarm condition by TOGGL.ING AND HOLDING the corresponding $120 \mathrm{~V}$ switched input switch.

5.8.25 VERIFY light is NOT ILLUMINATED on PLC module 5 input 7 (the FGM-2 input) located in the Interconnect Enclosure).

5.8.26 VERIFY strobe is FLASHING.

5.8.27 VERIFY horn is SOUNDING.

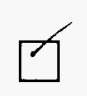

5.8.27 VERIFY horn is SOUNDING.

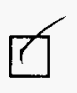

5.8.28 VERIFY jet pump is SHUTDOWN.

5.8.29 USING the DTAM, VERIFY the heat trace for the jet pump

jumper is OFF.

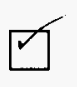
5.8.30 USING the DTAM, VERIFY the heat trace for the dip tubes is
OFF.
5.8.31 VERIFY "Alarm 12 JET PUMP SHUTDOWN" is DISPLAYED on the DTAM.
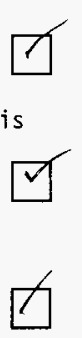

5.8.32 ACKNONLEDGE the alarm by PRESSING " $Y$ ".

0




\subsection{INTERLOCKS (continued)}

5.8.33 VERIFY strobe is NOT FLASHING.

5.8.34 VERIFY horn is OFF.

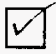
5.8.35 VERIFY "Alarm 19 Pump Pit FGM HIGH" is DISPLAYED on the
DTAM.
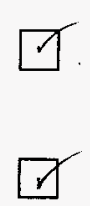

5.8.36 ACKNONLEDGE the alarm by PRESSING " $\gamma$ ".

5.8.37 USING the DTAM's Main Menu, VERIFY "Alarm 12 JET PUMP SHUTDOWN" and "Alarm 19 Pump Pit FGM HIGH" are displayed as IN ALARM.

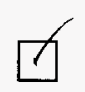

5.8.38 RELEASE the corresponding FGM \#2 120V switched input switch

$$
\text { Twan on two 3/18/96 }
$$

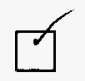

5.8.39 USING the DTAM, VERIFY the heat trace for the jet pump. jumpor is ON.

$$
\text { Tuas on thes 3/18/4c }
$$

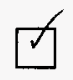

5.8.40 USING the DTAM, VERIFY the heat trace for the dip tubes. is ON.

5.8.41 USING the DTAM's Main Menu, VERIFY "Alarm 19 Pump Pit FGM HIGH" has CLEARED.

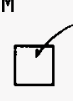

NOTE - When the jet pump is restarted the "Alarm 12 JET PUMP SHUTDOWN" will automatically clear.

5.8.42 RESTART the Jet pump USING the DTAM.

5.8.43 SIMULATE a MTC alarm condition by TOGGLING AND HOLDING the corresponding $120 \mathrm{~V}$ switched input switch. 


\subsection{INTERLOCKS (continued)}

5.8.44 VERIFY light is NOT ILLUMINATED on PLC module 5 input 8 (the MTC input) located in the Interconnect Enc:losure).

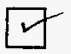

5.8.45 VERIFY strobe is FLASHING.

5.8.46 VERIFY horn is SOUNDING.

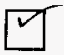

5.8 .47 VERIFY jet pump is SHUTDOWN.
5.8 .48 VERIFY "Alarm 12 JET PUMP SHUTDOWN" is DISPLAYED on the
DTAM.
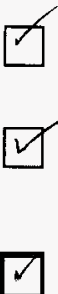

5.8.49 ACKNOWLEDGE the alarm by PRESSING "Y".

5.8.50 VERIFY strobe is NOT FLASHING.

5.8.51 VERIFY horn is OFF.

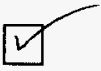

5.8.50 VERIFY strobe is NOT FLASHING.

5.8.51 VERIFY horn is OFF.

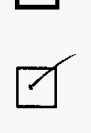
5.8.52 VERIFY "Alarm 20 MOTOR TEMPERATURE CUTOUT" is DISPLAYED on the DTAM.

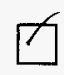

5.8.53 ACKNOWLEDGE the alarm by PRESSING " $\gamma$ ".

5.8.54 USING the DTAM's Main Menu, VERIFY "Alarm 12 JET PUMP SHUTDOWN" and "Alarm 20 MOTOR TEMPERATURE CUTOUT" are displayed as IN ALARM.
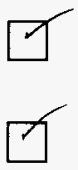

7 


\subsection{INTERLOCKS (cont inued)}

5.8.56 USING the DTAM's Main Menu, VERIFY "Alarm 20 MOTOR TEMPERATURE CUTOUT" has CLEARED.

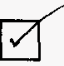

NOTE - When the jet pump is restarted the "Alarm 12 JET PUMP SHUTDOWN" will automatically clear.

5.8.57 RESTART the jet pump USING the DTAM.

5.8.58 SIMULATE a tank AN-101 alarm condition by TOGGLING AND HOLDING the corresponding I20V switched input switch.

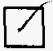

5.8.59 VERIFY light is NOT ILLUMINATED on PLC module 5 input 9 (the COMBINED AN-101 INTERLOCK input) located in the Interconnect Enclosure).

5.8.60 VERIFY strobe is FLASHING.

5.8.61 VERIFY horn is SOUNDING.

5.8.62 VERIFY jet pump is SHUTDOWN.
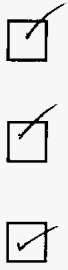

5.8.63 VERIFY "Alarm 12 JET PUMP SHUTDOWN" is DISPLAYED on the DTAM.

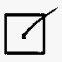

5.8.64 ACKNOWLEDGE the alarm by PRESSING " $Y$ ".

5.8.65 VERIFY strobe is NOT FLASHING.

5.8.66 VERIFY horn is OFF.
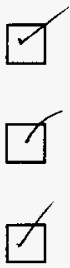


\subsection{INTERLOCKS (continued)}

5.8.67 VERIFY "Alarm 21 COMBINED AN-101 INTERLOCK" is DISPLAYED on the DTAM.

5.8.68 ACKNOWLEDGE the alarm by PRESSING " $Y$ ".

5.8.69 USING the DTAM's Main Menu, VERIFY "Alarm 12 JET PUMP SHUTDOWN" and "Alarm 21 COMBINED AN-101 INTERLOCK" are displayed as IN ALARN.

5.8.70 RELEASE the corresponding AN-101 interlock $120 \mathrm{~V}$ switched input switch.

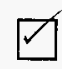

5.8.71 USING the DTAM's Main Menu, VERIFY "Alarm 21 COMBINED AN-101 INTERLOCK" has CLEARED.

NOTE - When the jet pump is restarted the "Alarm 12 JET PUMP SHUTDOWN" will automatically clear.

5.8.72 RESTART the Jet pump USING the DTAM.

5.8.73 SIMULATE an A/AX valve pits and/or clean out boxes alarm condition by TOGGLING AND HOLDING the corresponding $120 \mathrm{~V}$ switched input switch.

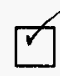

5.8.74 VERIFY light is NOT ILLUMINATED on PLC module 5 input 10 (the COMBINED A/AX VALVE PIT COB LEAK input) located in the Interconnect Enclosure).

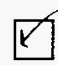

5.8.75 VERIFY strobe is FLASHING.

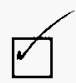

5.8.76 VERIFY horn is SOUNDING.

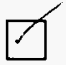




\subsection{INTERLOCKS (continued)}

5.8.77 VERIFY jet pump is SHUTDOWN.

5.8.78 VERIFY "Alarm 12 JET PUMP SHUTDOWN" is DISPLAYED on the DTAM.

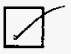

5.8.79 ACKNOWLEDGE the alarm by PRESSING " $Y$ ".

5.8.80 VERIFY strobe is NOT FLASHING.

5.8.81 VERIFY horn is OFF.

5.8.82 ACKNOWLEDGE the alarm by PRESSING " $Y$ ".

5.8.83 VERIFY "Alarm 22 COMBINED A/AX VALVE PIT COB LEAK" is STILL DISPLAYED on the DTAM.
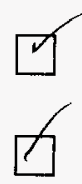

5.8.84 USING the DTAM' S Main Menu, VERIFY "Alarm 12 JET PUMP
SHUTDOWN" and "Alarm 22 COMBINED A/AX VALVE PIT COB LEAK" are displayed as IN ALARM.
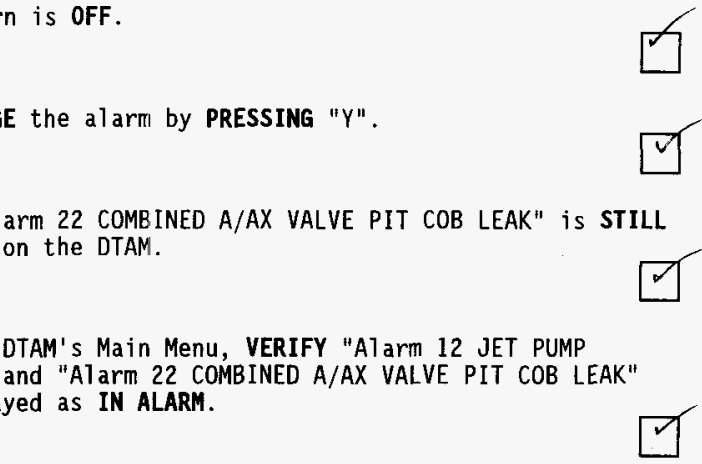

5.8.85 RELEASE the corresponding $A / A X$ valve pits and/or clean out boxes $120 \mathrm{~V}$ switched input switch.

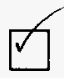

5.8.86 USING the DTAM's Main Menu, VERIFY "Alarm 22 COMBINED A/AX VALVE PIT COB LEAK" has CLEARED.

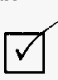

NOTE - When the jet pump is restarted the "Alarm 12 JET PUMP SHUTDOWN" will automatically clear.

5.8.87 RESTART the Jet pump USING the DTAM.

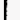




\subsection{INTERLOCKS (continued)}

5.8.88 SIMULATE a manual master shutdown trip condition by TOGGLING AND HOLDING the corresponding $120 \mathrm{~V}$ switched input switch.

5.8.89 VERIFY light is NOT ILLUMINATED on PLC module 5 input 11 (the manual master shutdown input) located in the Interconnect Enclosure).

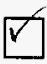

5.8.90 VERIFY strobe is FLASHING.

5.8.91 VERIFY horn is SOUNDING.

5.8.92 VERIFY jet pump is SHUTDOWN.

5.8 .93 VERIFY "Alarm 12 JET PUMP SHUTDOWN" is DISPLAYED on the
DTAM.

5.8 .93 VERIFY "Alarm 12 JET PUMP SHUTDOWN" is DISPLAYED on the
DTAM.
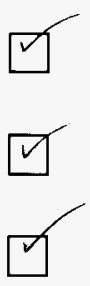

5.8.94 ACKNOWLEDGE the alarm by PRESSING " $Y$ ".

5.8.96 VERIFY horn is OFF.

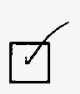
5.8.95 VERIFY strobe is NOT FLASHING.
5.8.94 ACKNOMLEDGE the alarm by PRESSIMG "Y".
VERIFY strobe is NOT FLASHIMG.
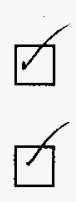
5.8.97 VERIFY "Alarm 23 MANUAL MASTER SHUTDOWN" is DISPLAYED on the
DTAM.

5.8.98 ACKNOWLEDGE the alarm by PRESSING "Y".

\begin{tabular}{l|l}
\hline Document No. & Rev/Mod \\
\end{tabular}

0




\subsection{INTERLOCKS (continued)}

5.8.99 USING the DTAM's Main Menu, VERIFY "Alarm 12 JET PUMP SHUTDOWN" and "Alarm 23 MANUAL MASTER SHUTDOWN" are displayed as IN ALARI .

5.8.100 RELEASE the corresponding manual master shutdown $120 \mathrm{~V}$ switched input switch.

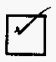

5.8.101 USING the DTAM's Main Menu, VERIFY "ATarm 23 MANUAL MASTER SHUTDOWN" has CLEARED.

NOTE - When the jet pump is restarted the "Alarm 12 JET PUMP SHUTOOWN" will automatically clear.

5.8.102 RESTART the Jet pump USING the DTAM.

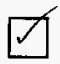

5.8.103 SIMULATE a dome pressure \#1 alarm condition by TOGGLING AND HOLDING the corresponding $120 \mathrm{~V}$ switched input switch.

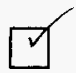

5.8.104 VERIFY light is NOT ILLUMINATED on PLC module 5 input 12 (the dome pressure \#1 input) located in the Interconnect Enclosure).

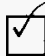

5.8.105 VERIFY strobe is FLASHING.

5.8.106 VERIFY horn is SOUNDING.

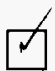

\subsubsection{VERIFY horn is SOUNDING.}

5.8.107 VERIFY jet pump is SHUTDOWN.

5.8.108 USING the DTAM, VERIFY the heat trace for the jet pump jumper is OFF.

WHC-SD-WM-ATR-171 


\subsection{INTERLOCKS (continued)}

5.8.109 USING the DTAM, VERIFY the heat trace for the dip tubes is OFF.

5.8.110 VERIFY "Alarm 12 JET PUMP SHUTDOWN" is DISPLAYED on the DTAM.

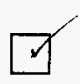

5.8.111 ACKNOWLEDGE the alarm by PRESSING " $\gamma$ ".

5.8.112 VERIFY strobe is NOT FLASHING.

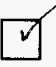

5.8.113 VERIFY horn is OFF.

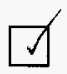

5.8.114 VERIFY "Alarm 24 DOME. PRESSURE \# 1 HIGH" is DISPLAYED on the DTAM.

5.8.115 ACKNOWLEDGE the alarm by PRESSING "Y".

5.8.116 USING the DTAM's Main Menu, VERIFY "Alarm 12 JET PUMP SHUTDOWN" and "Alarm 24 DOME PRESSURE \#l HIGH" are displayed as IN ALARM.

5.8.117 RELEASE the corresponding dome pressure \#1 120V switched input switch.

$$
\begin{array}{r}
\text { Tho } 3 / 18 / 91 \\
\text { Turn on on } 3 / 18 / 94
\end{array}
$$

5.8.118 USING the DTAM, VERIFF the heat trace for the jet pump. jumper is - ON:

$$
\text { Tuan on Tw 3/18/96 }
$$

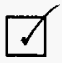

5.8.119 USING the DTAM, VERIf $¥$ the heat trace for the dip tubes. is. ON.

0




\subsection{INTERLOCKS (continued)}

5.8.120 USING the DTAM's Main Menu, VERIFY "Alarm 24 DOME PRESSURE \#1 HIGH" has CLEARED.

NOTE - When the jet pump is restarted the "Alarm 12 JET PUMP SHUTDOWN" will automatically clear.

5.8.121 RESTART the jet pump USING the DTAM.

5.8.122 SIMULATE a dome pressure \#2 alarm condition by TOGGLING AND HOLDING the corresporiding $120 \mathrm{~V}$ switched input switch.

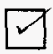

5.8.123 VERIFY light is NOT ILLUMINATED on PLC module 5 input 13 (the dome pressure \#2 input) located in the Interconnect Enclosure).

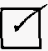

5.8.124 VERIFY strobe is FLASHING.

5.8.125 VERIFY horn is SOUNDING.

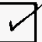

5.8.126 VERIFY jet pump is SHUTDOWN.

5.8.127 USING the DTAM, VERIFY the heat trace for the jet pump jumper is OFF.

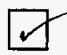

5.8.128 USING the DTAM, VERIFY the heat trace for the dip tubes is OFF.

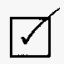

5.8.129 VERIFY "Alarm 12 JET PUMP SHUTDOWN" is DISPLAYED on the DTAM.

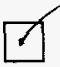

5.8.130 ACKNOWLEDGE the alarm by PRESSING " $Y$ ". 


\subsection{INTERLOCKS (continued)}

5.8.131 VERIFY strobe is NOT FLASHING.

5.8.132 VERIFY horn is OFF.

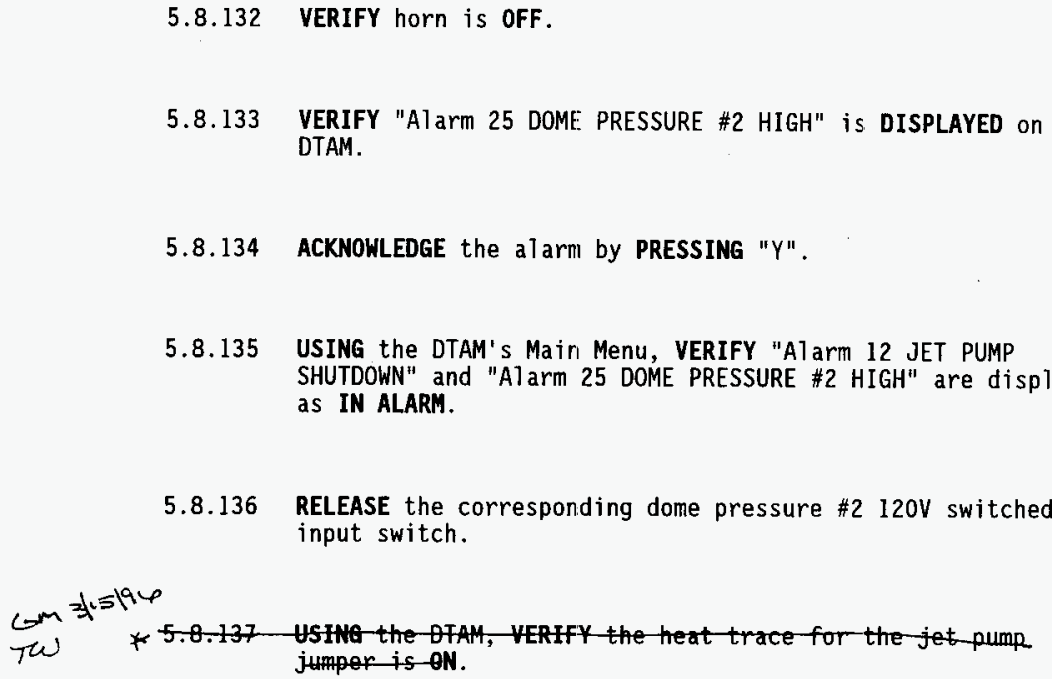

5.8.133 VERIFY "Alarm 25 DOME PRESSURE \#2 HIGH" is DISPLAYED on the

5.8.134 ACKNOWLEDGE the alarm by PRESSING " $\gamma$ ".

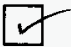

5.8.135 USING the DTAM's Main Menu, VERIFY "Alarm 12 JET PUMP SHUTDOWN" and "Alarm 25 DOME PRESSURE \#2 HIGH" are displayed S IN ALARM.

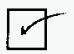

5.8.136 RELEASE the corresponding dome pressure \#2 $120 \mathrm{~V}$ switched input switch.

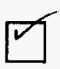

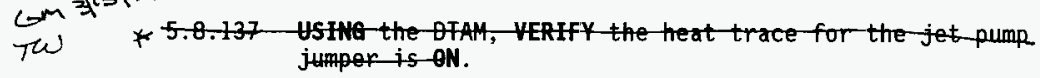

*5.8.138- USING the DFAA, VERIFY the heat trace for the dip tubes-isON.

5.8.139 USING the DTAM's Main Menu, VERIFY "Alarm 25 DOME PRESSURE \#2 HIGH" has CLEARED.
* NOIE — When the jet pump is restarted the "ATarm 12 JET-PUAP SHUFDOWH" will automatically clear.
廿 5.8.140-RESTART the det pump-USTNG-the OTAM-

(n)




\subsection{INTERLOCKS (continued)}

\section{WARNING}

Energized circuits and leads are contained inside the cabinet. observe appropriate electrical precautions.

* 5.8.141- D SCONEEF the 120 V switehed imput from terminats 7 through 14- of the phoen $1 x$ comnector focated in the Interconnest Enctosure.).

5.8.142 Test Director SHALL VERIFY that section 5.8 is complete by signing below.

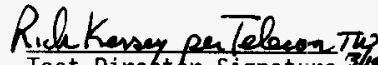

Test Direttor Signature $3 / 0 / 6$

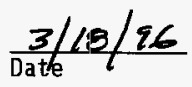

5.8.143 QC Inspector SHALL VERIFY that section 5.8 is complete by signing below.

$\frac{\text { cezorze MNTA }}{\text { QC Inspector Signature }} \frac{\text { slis/ie }}{\text { Date }}$

0




\subsection{JET PUMP VALVING INTERILOCK}

5.9.1 PLACE the AX-101 saltwell jumper JR-1 valve in the PROCESS position.

5.9.2 ENSURE Pump recirculation apparatus is filled with water AND CONFIGURED to circulate water through the saltwell Jet pump.

5.9.3 VERIFY no alarms are ANNUNCIATING at the DTAM.

5.9.4 START the A-101 jet pump USING the DTAM.

5.9.5 START the AX-101 jet pump USING the DTAM.

5.9.5 START the AX-101 jet pump USING the DTAM.
P.9.6 PLACE the AX-101 JR-1 Valve on the Jet Pump Jumper in the
PRIME position.

5.9.5 START the AX-101 jet pump USING the DTAM.
P.9.6 PLACE the AX-101 JR-1 Valve on the Jet Pump Jumper in the
PRIME position.
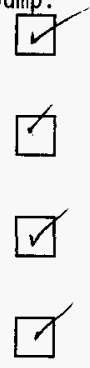

5.9.7 VERIFY the following:

5.9.7.1 AX-101 jet Pump IMMEDIATELY SHUTS DOWN.

5.9.7.2 A-101 jet Pump CONTINUES to opelrate.

5.9.7.3 "ALARM 5 JR-1 Position NOT PROCESS" is DISPLAYED at DTAM. 5.9.7.4 "ALARM 12 JET PUMP SHUTDOWN" is DISPLAYED at the
DTAM.
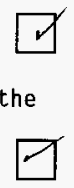

5.9.8 PLACE the AX-101 JR-1 Valve on the Jet Pump Jumper in the PROCESS position.

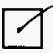

0


5.9.9 RESTART the AX-101 Jet pump USING the DTAM.

5.9.10 PLACE the AX-101 JR-1 Valve on the Jet Pump Jumper in the FLUSH position.

5.9.11 VERIFY the following:

5.9.11.1 A-101 jet Pump IMMEdiately SHUTS DOWN.

5.9.11.2 AX-101 jet Pump IMMEDIATELY SHUTS DOWN.

5.9.11.3 A-101 jet Pump CAN NOT be RESTARTED at the power enclosure with JR-1 in the FLUSH position.

5.9.11.4 AX-101 jet Pump CAN NOT be RESTARTED at the power enclosure with JR-1 in the FLUSH position.

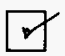

5.9.11.5 "ALARM 5 JR-1 POSition NOT PROCESS" is DISPLAYED at $A X-101$ DTAM.

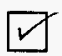

5.9.11.6 "ALARM 12 JET PUMP SHUTDOWN" is DISPLAYED at the Tw 3/18/96

5.9.12 RESTART the A-101 Jet pump USIMG the DTAM.

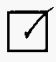

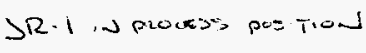

RESTART the A-101 Jet pump USIMG the DTAM.

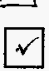

5.9.13 RESTART the AX-101 Jet pump USING the DTAM.

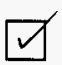

5.9.14 SHUTDOWN the AX-101 jet pump USING the DTAM.

5.9.15 WAIT APPROXIMATELY thirty (30) minutes, VERIFY the A-101 jet pump SHUTS DOWN.

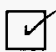

Rev/Mod

0


5.9.16 Test Director SHALL VERIFY that section 5.9 is complete by signing below.

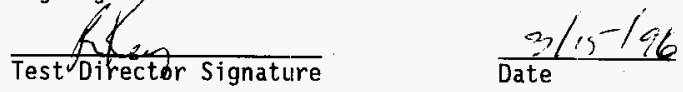

5.9.17 QC Inspector SHALL VERIFY that section 5.9 is complete by signing below.

$\frac{\text { QCenez-MAin }}{\text { QC Inspector Signature }} \quad \frac{3 / 5 / 96}{\text { Date }}$




\section{FIGURE 1: FLOW DIAGRAM INSTRUMIENT AIR AND WATER SYSTEMS}

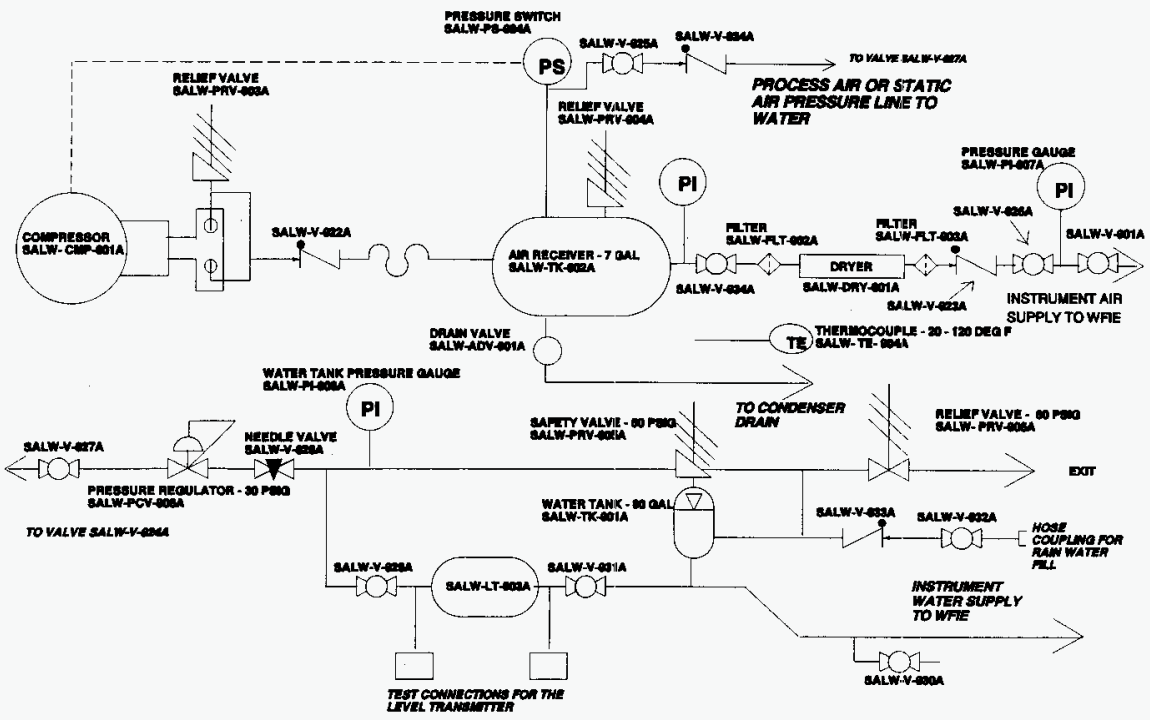


FIGURE 2: WEIGHT FACTOR INSTRUMENT ENCLOSURE FLOW SHEET

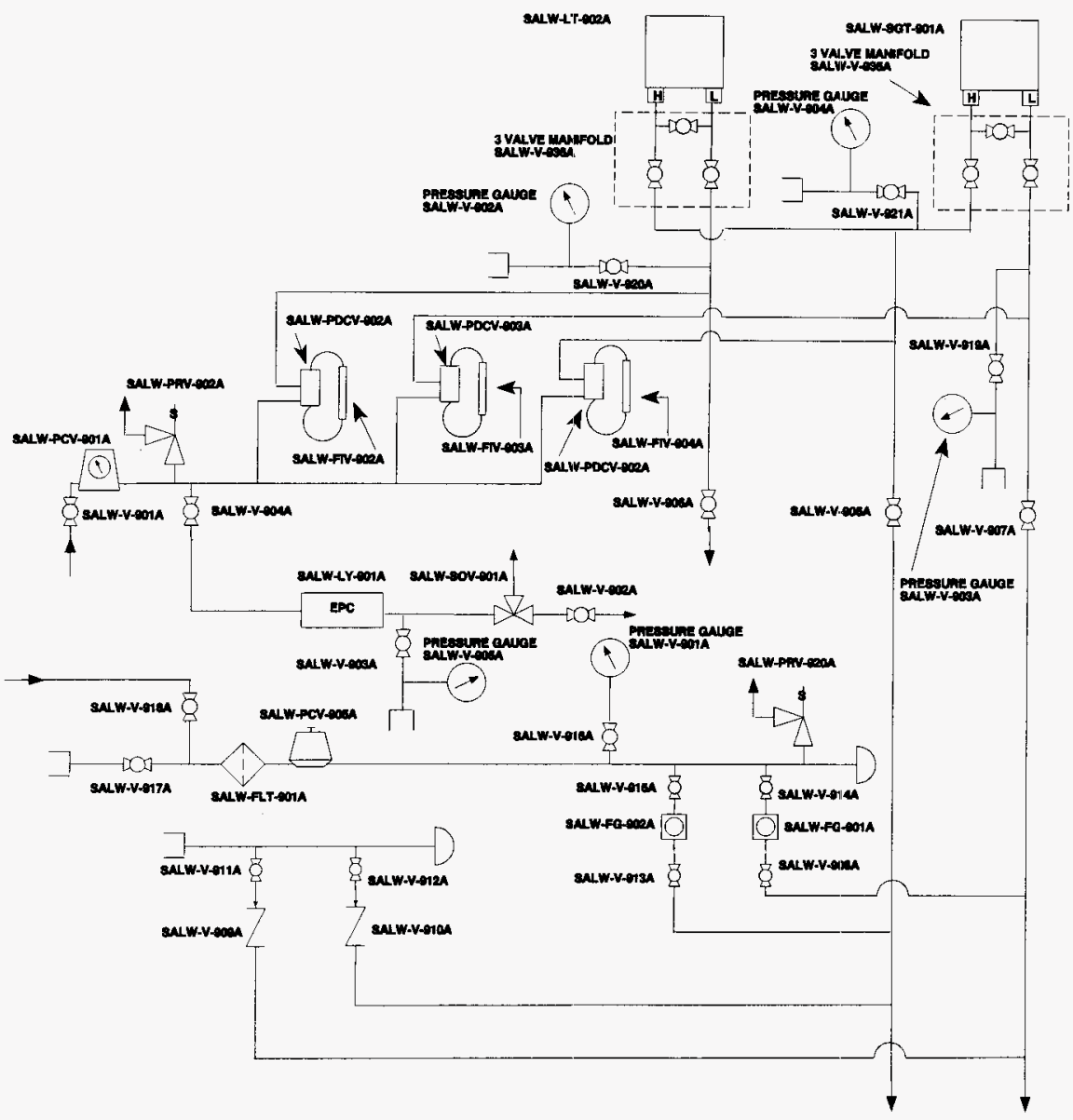

Document No.

Rev/Mod

0

Page.

WHC-SD-WM-ATR-171

0

62 
FIGURE 3: JUMPER TEST ASSEMBLY

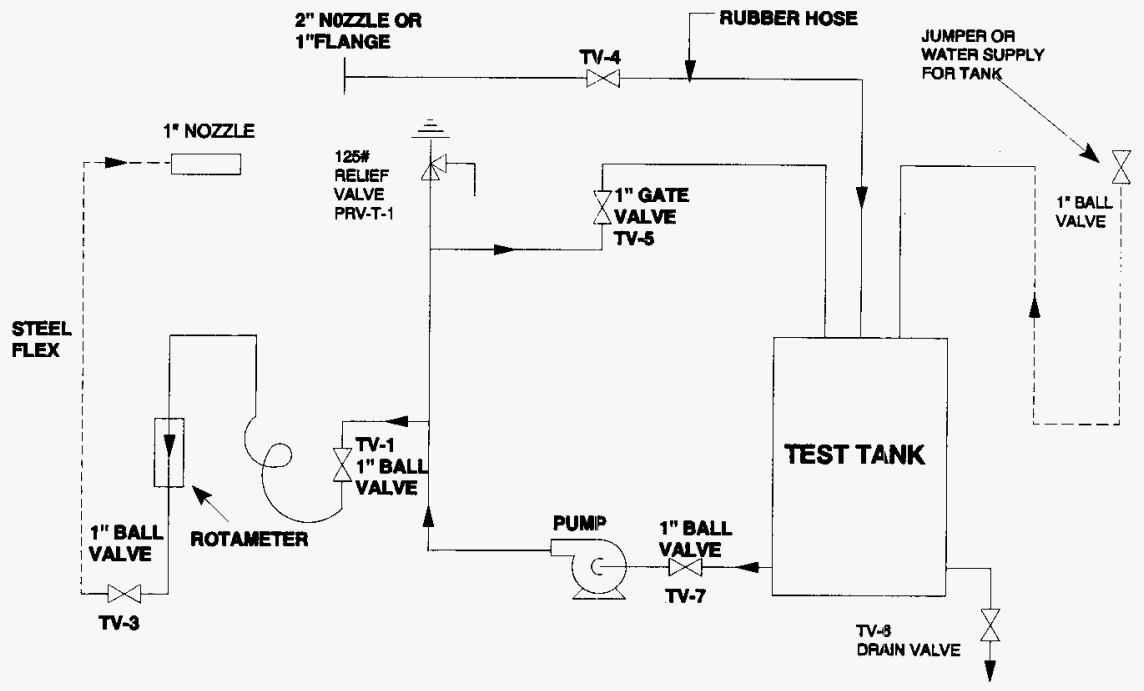




\section{FIGURE 4: JET PUMP JUMPER TEST CONNECTIONS}

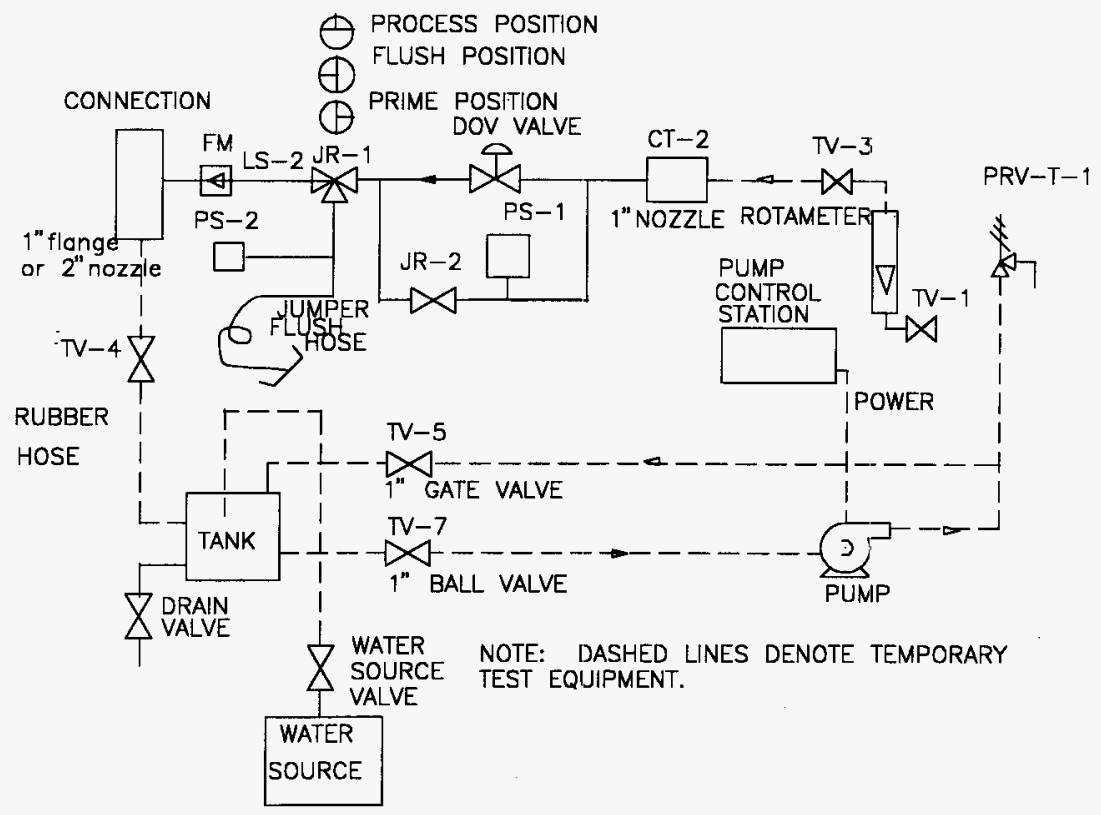


TANK FARM ACCEPTANCE TEST PROCEDURE

ATP EXCEPTION LOG

This page may be reproduced as necessary

PAGE of

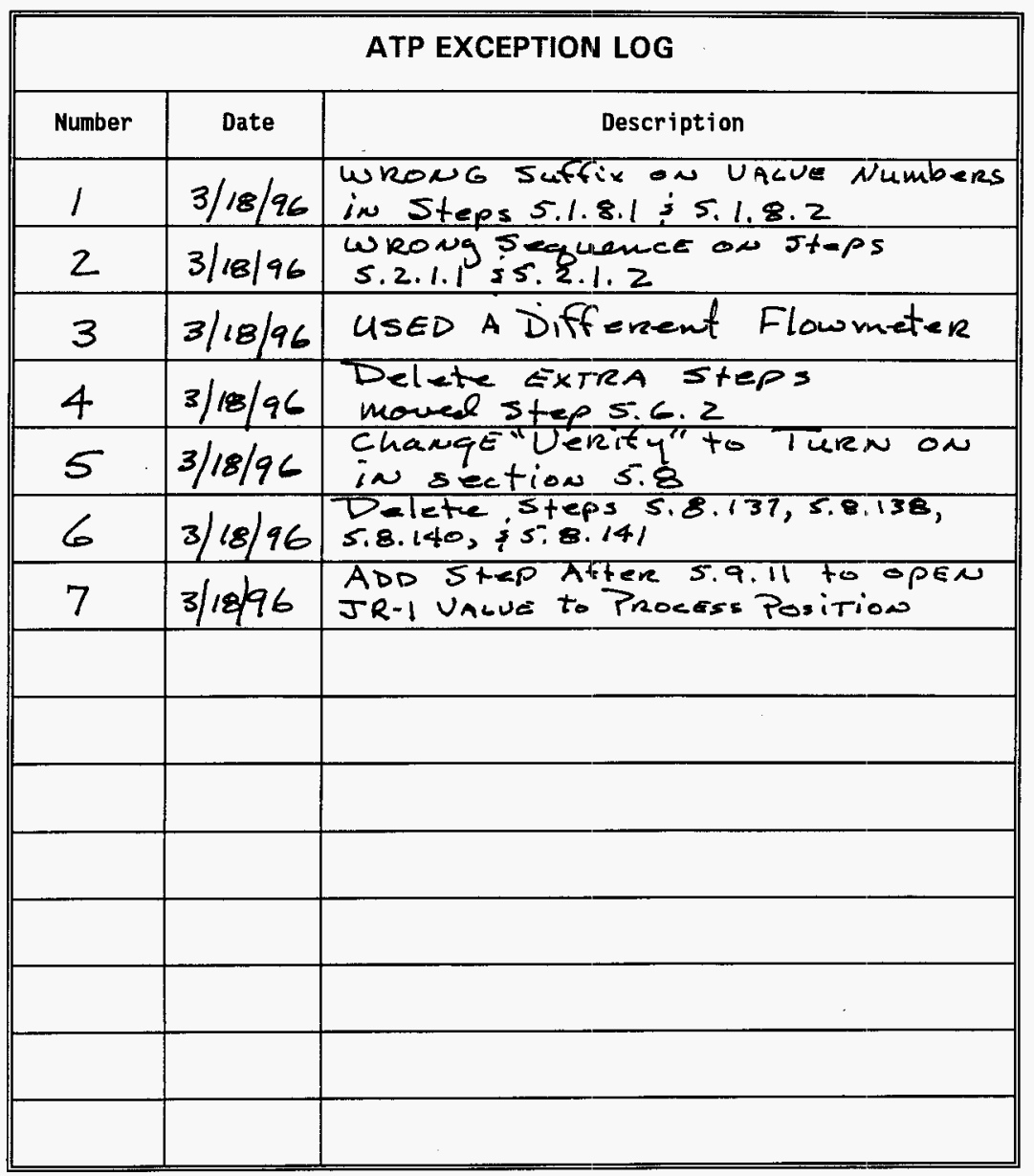

\begin{tabular}{|l|l|ll|}
\hline $\begin{array}{l}\text { Document No. } \\
\text { WHC-SD-WM-ATR-171 }\end{array}$ & Rev/Mod & Page & 65 \\
\hline
\end{tabular}


TANK FARM ACCEPTANCE TEST PROCEDURE

ATP EXCEPTION RECORD

This page may be reproduced as necessary.

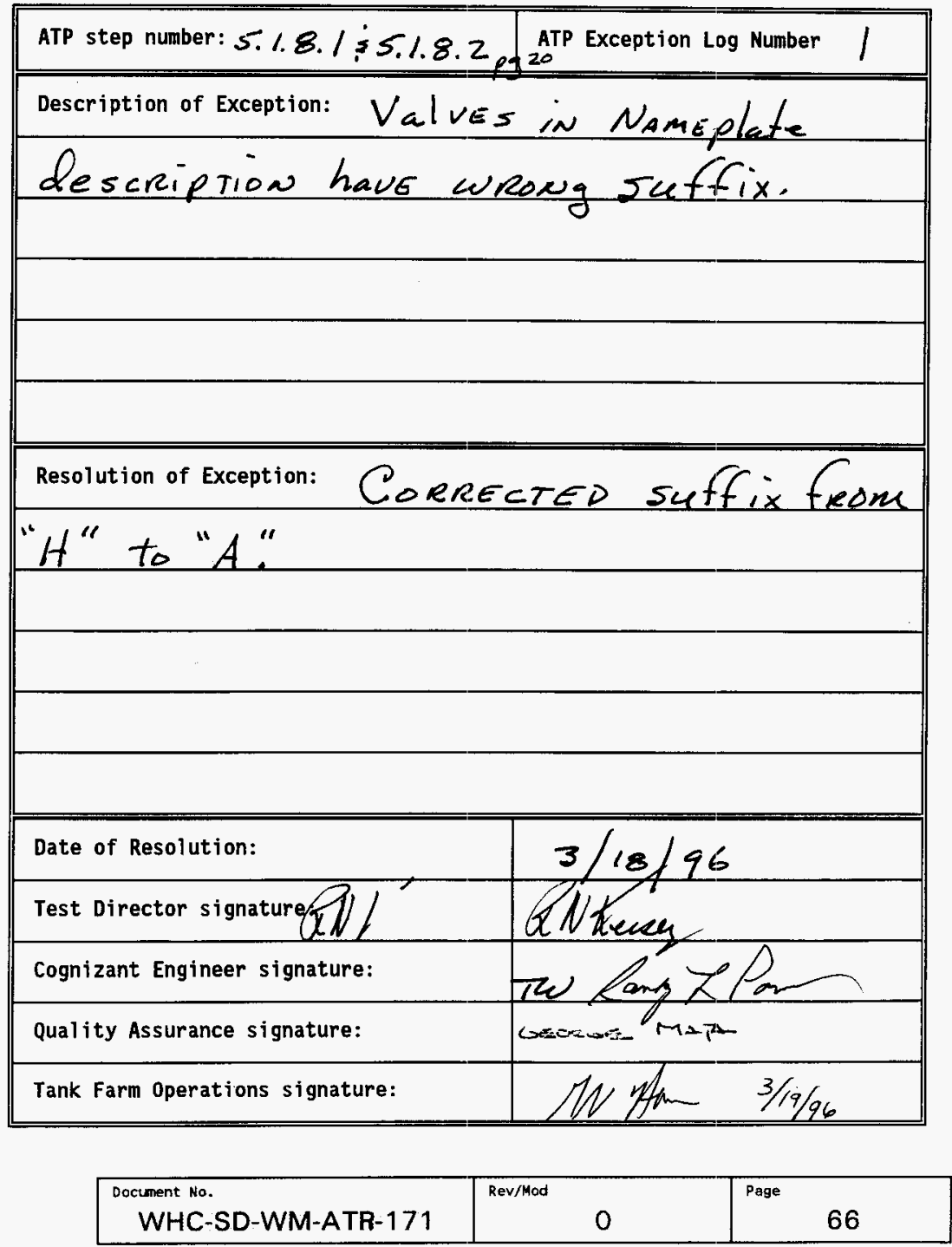




\begin{tabular}{|c|c|c|}
\hline$\forall 99$ & 0 & $l \angle l-8 \perp \forall-W M-a S-J H M$ \\
\hline
\end{tabular}

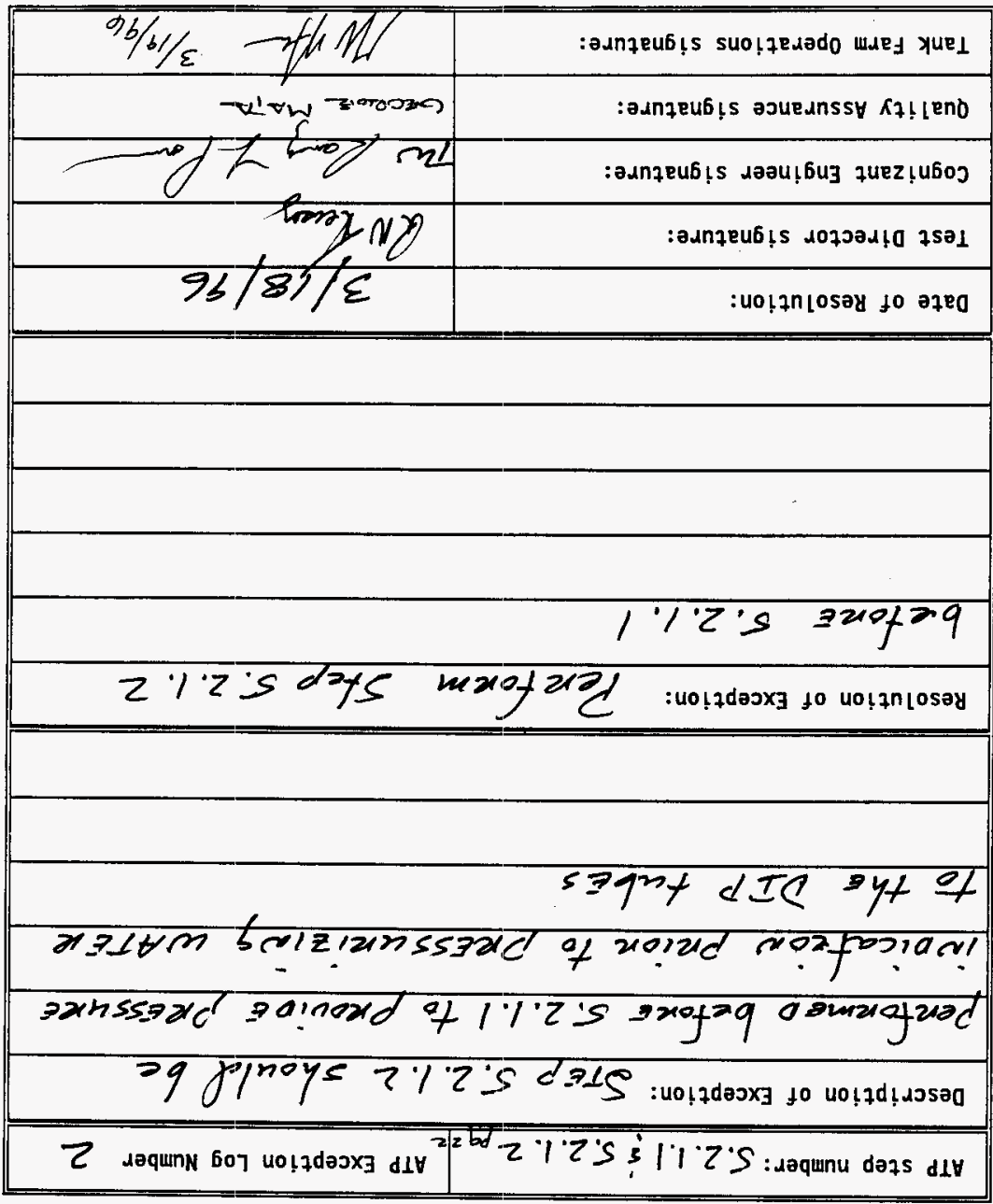

- Kлessajau se paonposdad aq Kew әбed s!प1

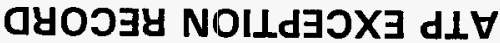


TANK FARM ACCEPTANCE TEST PROCEDURE

ATP EXCEPTION RECORD

This page may be reproduced as necessary.

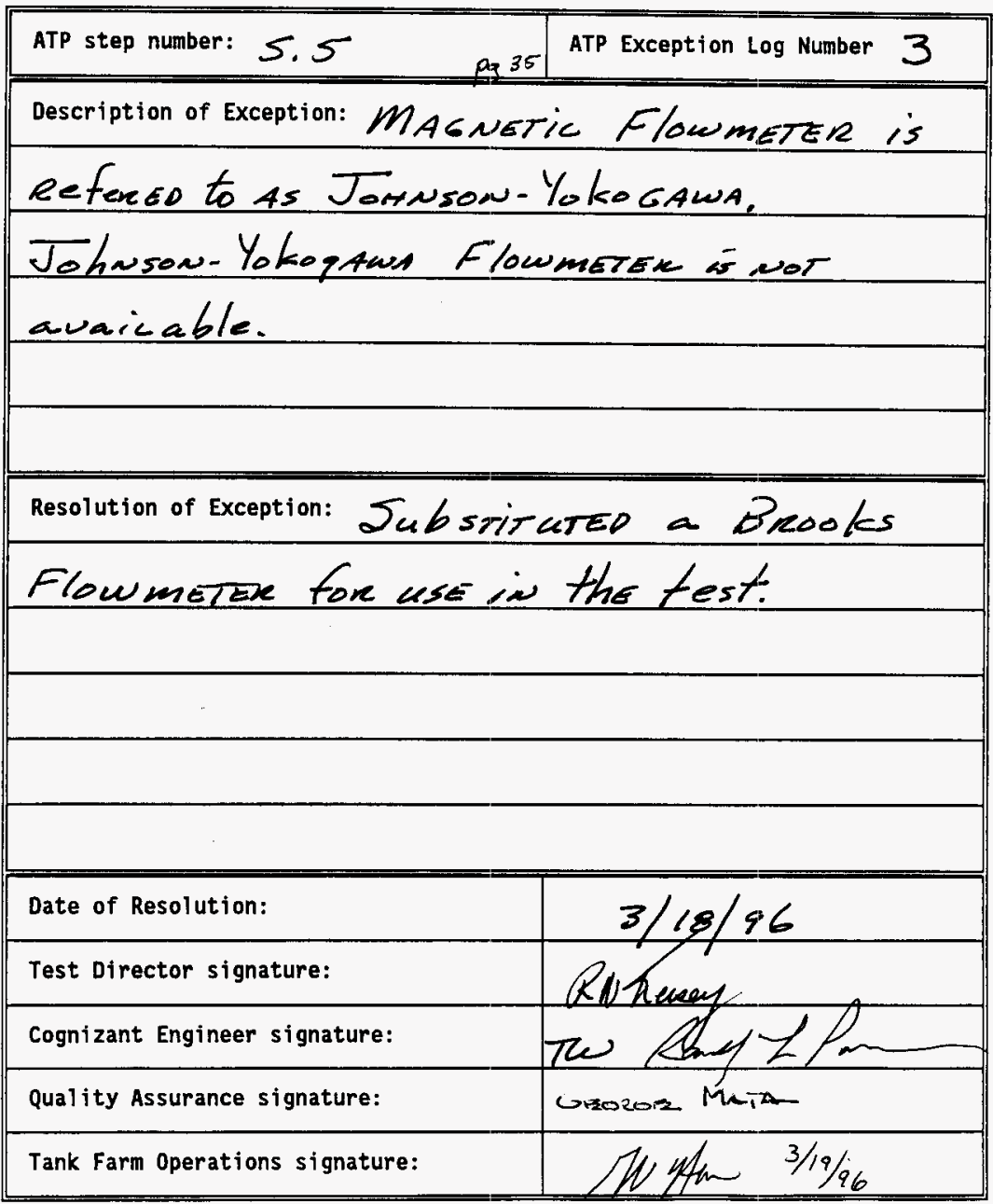

\begin{tabular}{|l|l|l|}
\hline $\begin{array}{l}\text { Document No. } \\
\text { WHC-SD-WM-ATR-171 }\end{array}$ & Rev/Mad & Page \\
\hline
\end{tabular}


TANK FARM ACCEPTANCE TEST PROCEDURE

ATP EXCEPTION RECORD

This page may be reproduced as necessary.

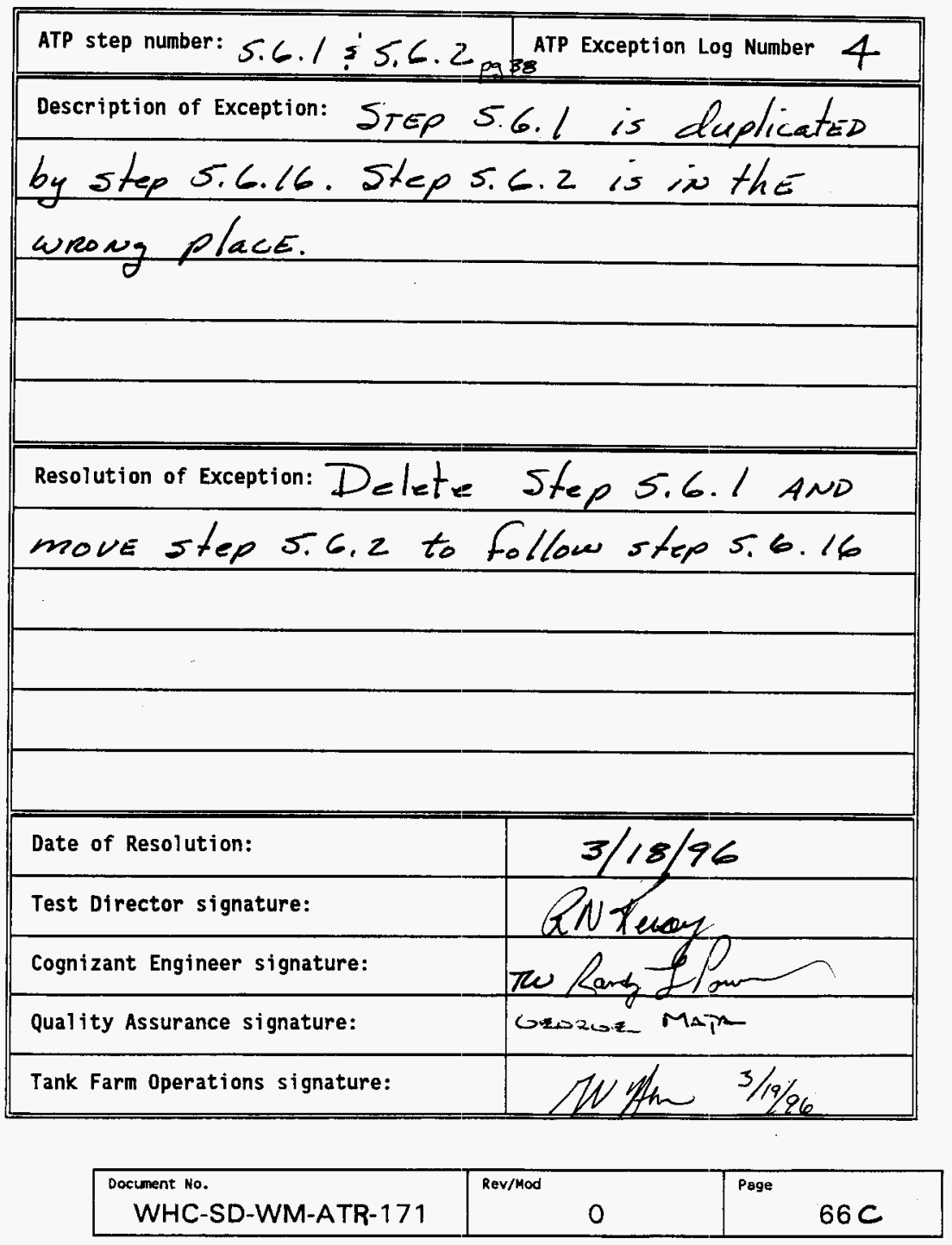


TANK FARM ACCEPTANCE TEST PROCEDURE

ATP EXCEPTION RECORD

This page may be reproduced as necessary.

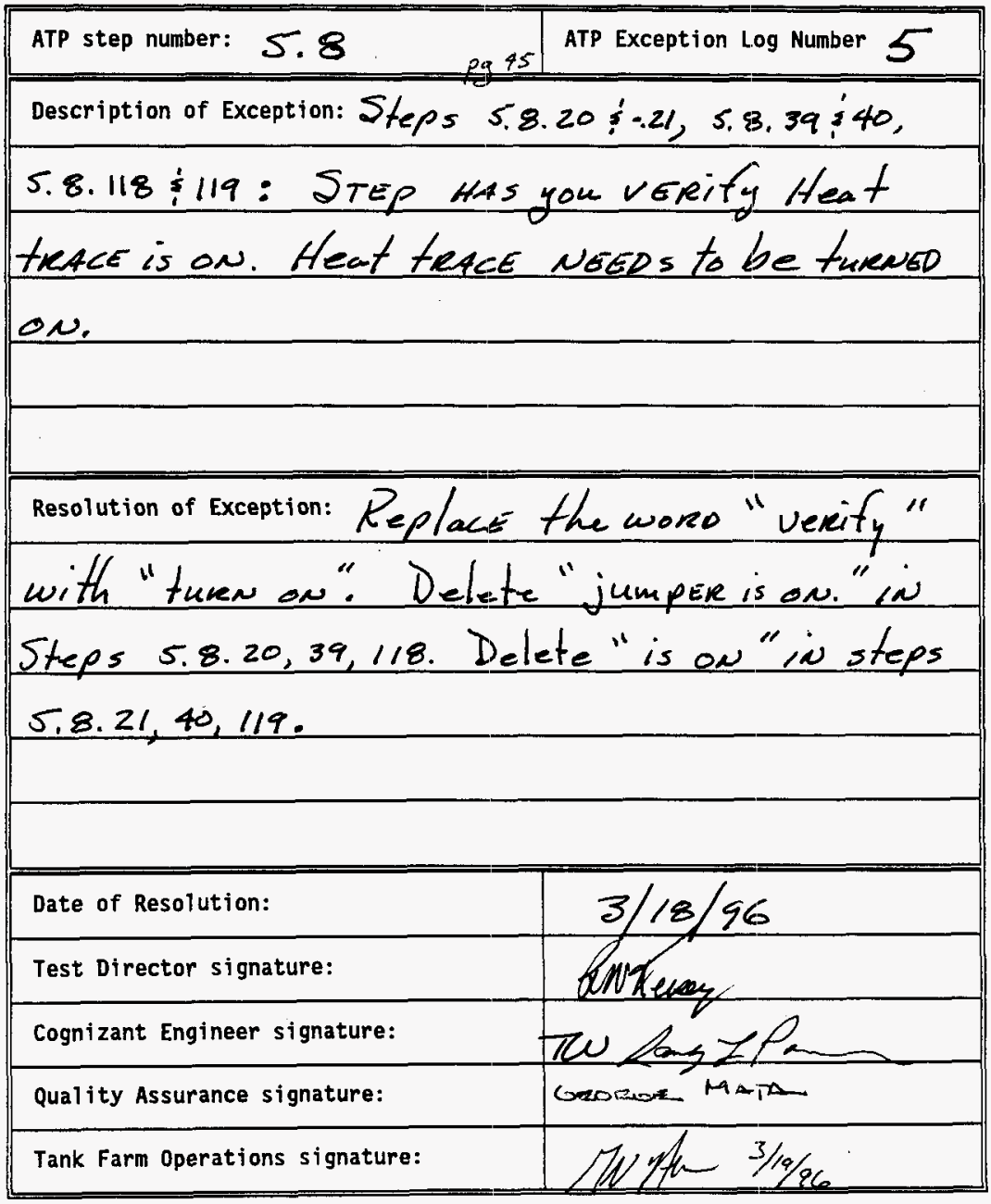

\begin{tabular}{|l|l|l|}
\hline $\begin{array}{l}\text { Document No. } \\
\text { WHC-SD-WM-ATR-171 }\end{array}$ & Rev/Mod & 0 \\
\hline
\end{tabular}


TANK FARM ACCEPTANCE TEST PROCEDURE

ATP EXCEPTION RECORD

This page may be reproduced as necessary.

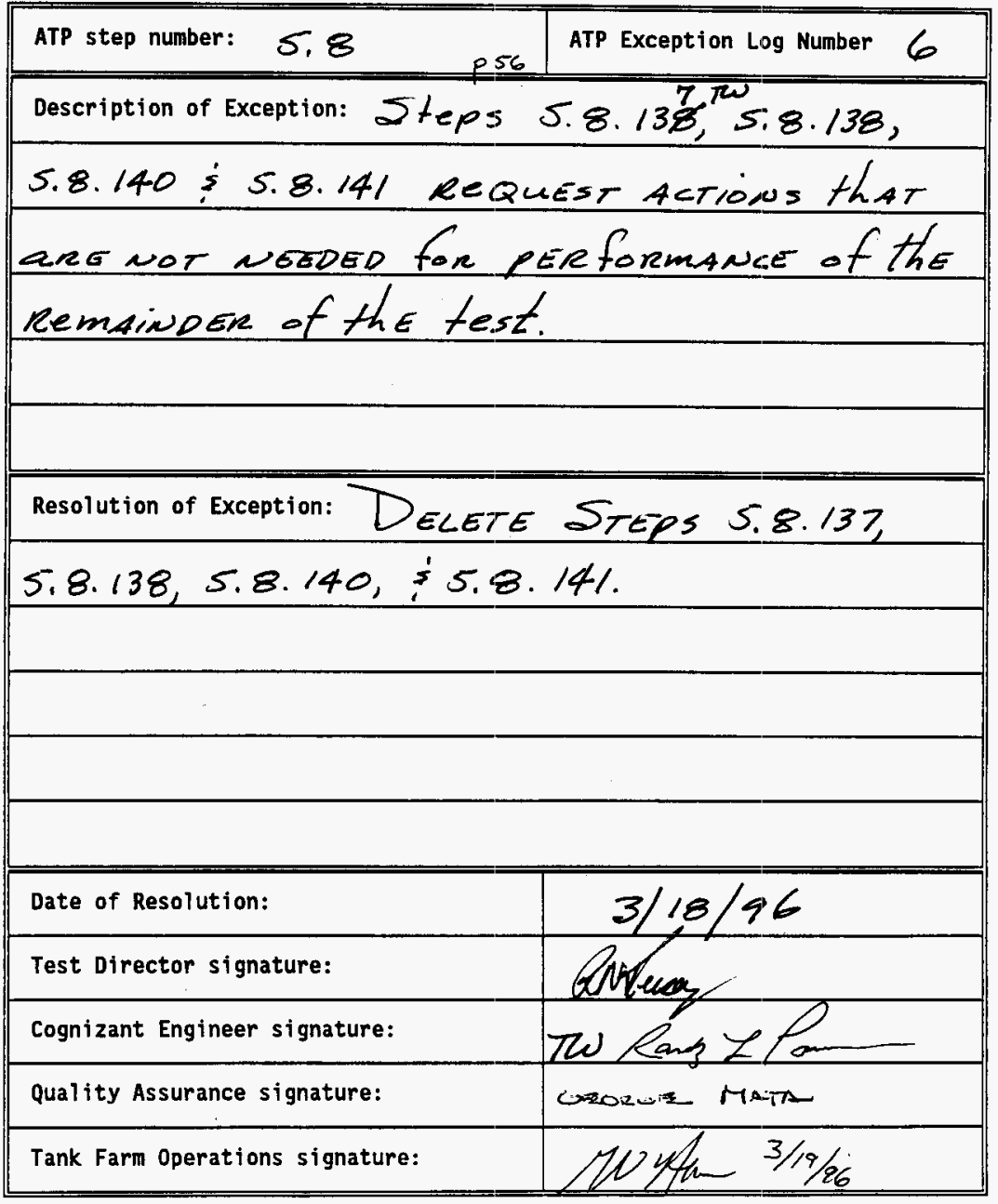

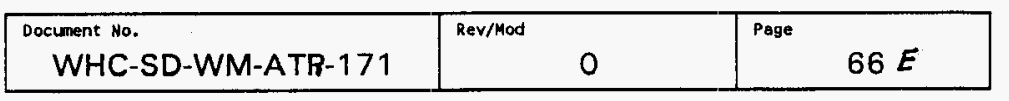


TANK FARM ACCEPTANCE TEST PROCEDURE

ATP EXCEPTION RECORD

This page may be reproduced as necessary.

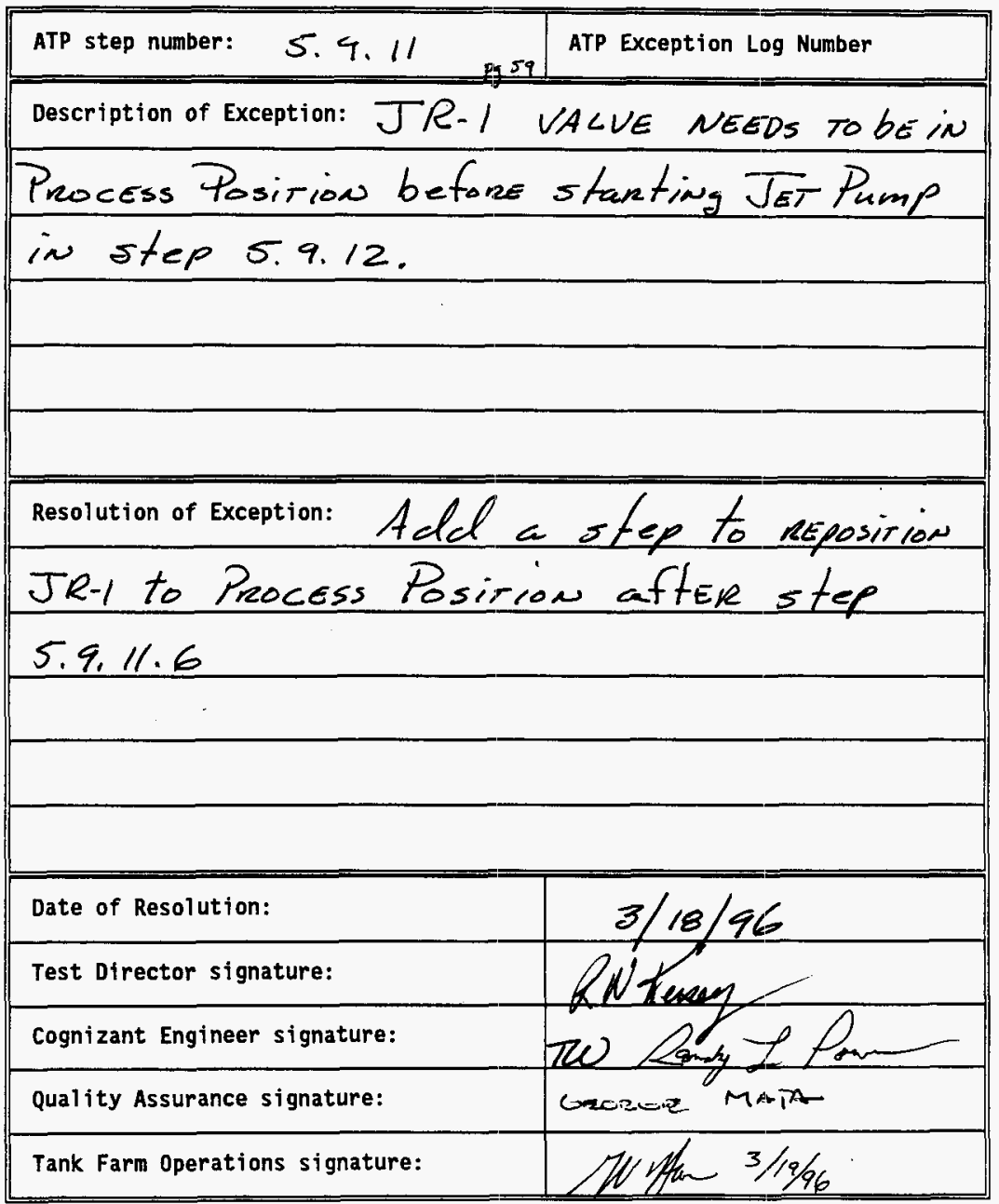

\begin{tabular}{|l|l|l|}
\hline $\begin{array}{l}\text { Document No. } \\
\text { WHC-SD-WM-ATR-171 }\end{array}$ & Rev/Mod & Page \\
\hline
\end{tabular}


TANK FARM ACCEPTANCE TEST PROCEDURE

ATP ACCEPTANCE RECORD

This ATP has been completed and the results, including redline changes, exceptions, and exception resolutions, have been reviewed for compliance with the intent of the Purpose (Section 1.0). The ATP results are accepted by the undersigned:
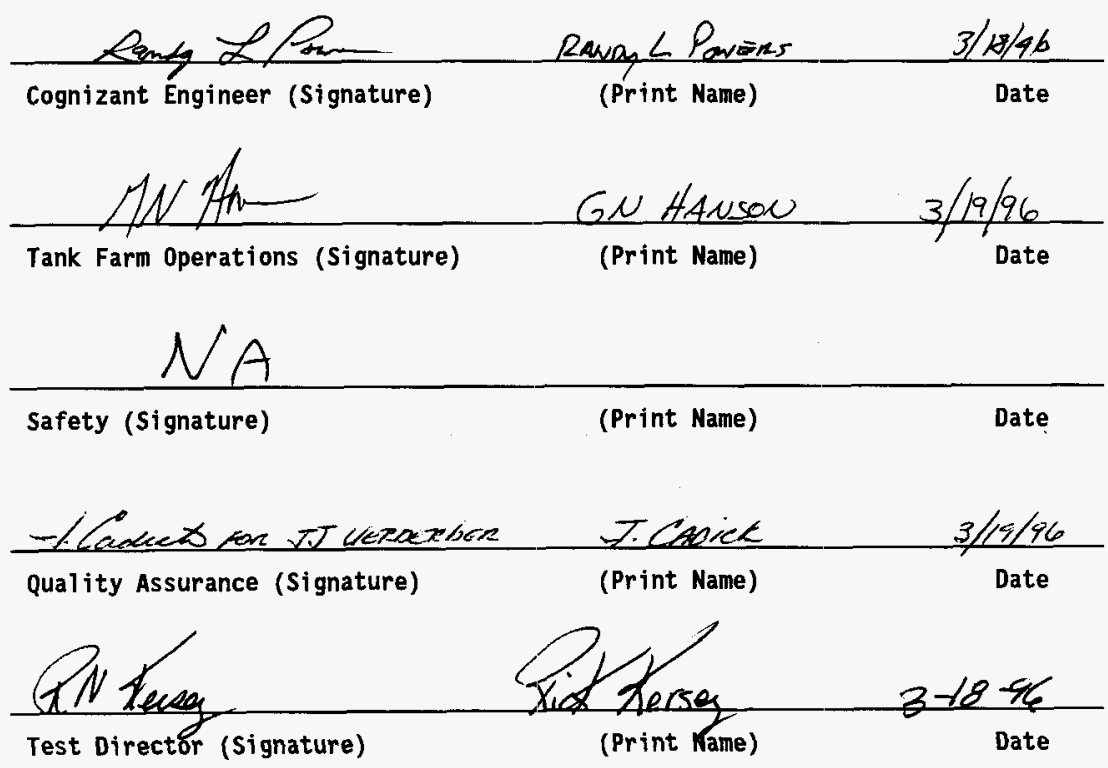

\begin{tabular}{|l|l|l|l|}
\hline $\begin{array}{l}\text { Document No. } \\
\text { WHC-SD-WM-ATR-171 }\end{array}$ & Rev/Mod & Page \\
\hline
\end{tabular}


Witc-SD-Wm-ATR-TI Ris

\section{PUMPING AND INSTRUMENTATION CONTROL SYSTEM (PICS)}

LEAK TEST PROCEDURE

\subsection{PURPOSE}

To ensure that all piping (air \& water service) is free of all leaks within typical operating pressures as specified in this procedure. This procedure is using a combination hydrostatic and pneumatic test in accordance with Engineering Change Notice (ECN) 629550.

\subsection{RESPONSIBILITIES}

PIC - Person In Charge - Shall ensure that the necessary requirements for compliance to this procedure are followed.

QA/QC - Quality Assurance/Control - Shall witness procedure steps where specified. Shall also concur on resolution of test exceptions

Cog. Engineer - Shall provide disposition on test exceptions. Shall approve test exceptions and final test results.

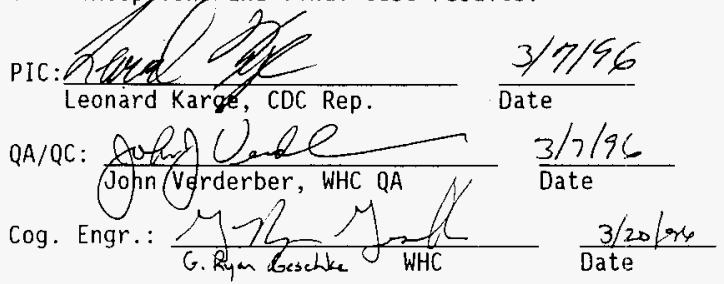

\subsection{PRE-TEST VERIFICATIONS}

TANK ID: $\mathrm{AX}-101$ SKID DESIGNATOR: I

3.1 Verify that power to the compressor (SALW-DS-904A) is OFF (Open)

3.2 Verify that valve $V-934 A$ is OPEN.

3.3 Verify that PI-906A \& 907A indicate 0 psig in air receiver tank.

3.4 Verify PI-901A is zero.

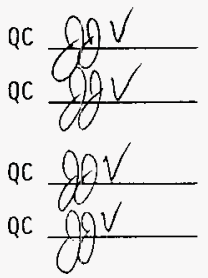


3.5 If the pressure in PI-901A is $>0$ psig, drain pressure by opening valve $V-914 A$. When PI-901A reaches 0 psig, CLOSE V-914A.

3.6 Verify that the following valves are CLOSED:

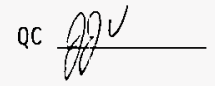
(y) $V-902 A$
(प) $V-905 A$
(广V V-914A
(U) $V-906 A$
(L) $V-907 A$
(L) $V-908 A$
(4) $V-913 A$
(c) $V-915 A$
$(+V-930 A$
(c) $V-932 A$
(c) $V-917 A$
(Y) V-937A

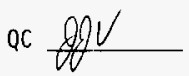

3.7 Verify that the following vaives are OPEN:
(Y) $V-934 A$
(f) $V-926 A$
(4) V-925A
(U) $V-901 A$
(C) V-927A
( $) ~ V-904 A$
(v) $V-928 \mathrm{~A}$
(v) $V-903 A$
(u) $V-929 A$
(v) $V-920 A$
(U) V-931A
(Y) $V-921 A$
(u) V-918A
(u) $V-919 A$
(u) V-916A
Equalizing Valves:
( $) ~ V-936 A$ (Middle - OPEN, Others - CLOSED)
( $) ~ V-935 A$ (Middle - OPEN, Others - CLOSED)

3.8 PIC to ensure that there is at least 9 gallons ( $10 \%$ full) of water in tank TK-901A. Minimum necessary $=10^{\prime \prime}$

RECORD

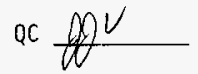

inches SEE EIC $\frac{\text { PL }}{\text { PTOW }}$ *

\subsection{INITIAL SERVICE LEAK TEST}

4.1 Turn on power to the air compressor by CLOSING SALW-DS-904A and placing the HAND-OFF-AUTO switch in AUTO.

4.2 Pressure in the air receiver tank as indicated by PI-906A and PI-907A should rise to approximately 90 psig $( \pm 5$ psig).

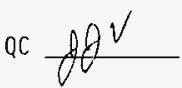

4.3 Once pressure has stabilized at approx.

90 psig ( \pm 5 psig), adjust PCV-901A to

22 psig ( \pm 1 psig) as indicated by

PI-902A, PI-903A, PI-904A and PI-905A.

Adjust PCV-906A to $36 \mathrm{psig}$ ( \pm 1 psig)

as indicated by PI-908A. Adjust

PCV-905A to 22 psig ( \pm I psig) as indicated by PI-901A. close valve salw-v-go $4 a *$

4.4 TURN OFF compressor by OPENING SALW-DS-904A * SEE EXCEPTION \# 2 


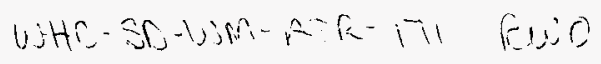

4.5 RECORD date/time and pressures as indicated by the following gauges:
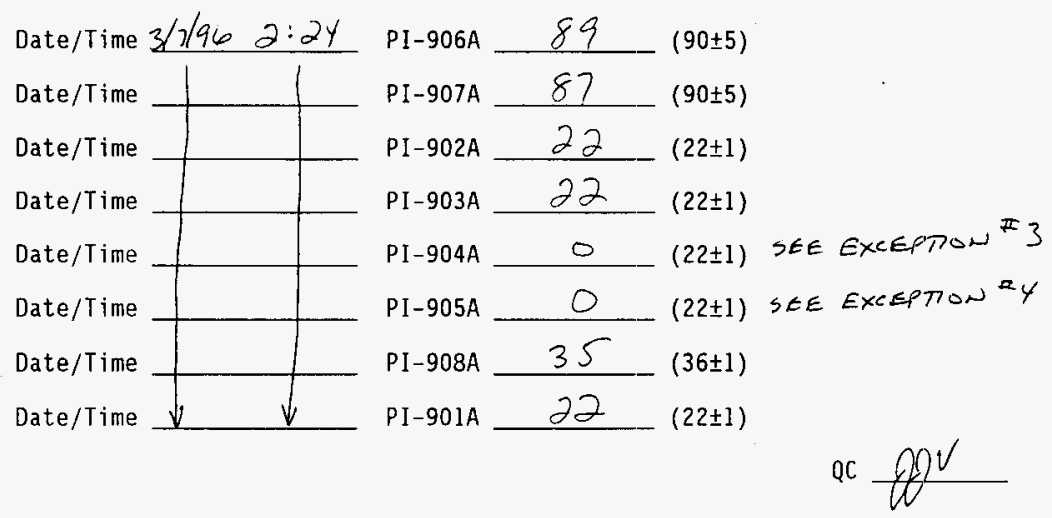

4.6 After 10 minutes has passed, record date/time and pressure:

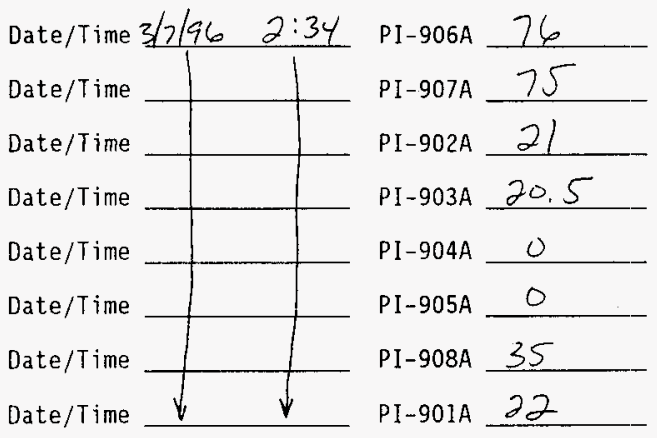

SEE ATTACHMENT FOR RETEST QQ V

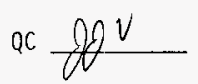

ACCEPTANCE CRITERIA: Pressure shall not drop by more than $5 \%$ from step 4.5 to 4.6. for any of the respective gauges. If leaks exist, repair and repeat test steps from step 3.1 .

The test has been performed in accordance with the procedure. Any leaks identified during testing have been corrected and a retest has been satisfactorily performed.

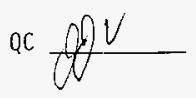

Ar 
WHE-SD-WM-ATE-M

RETEST gov

\subsection{RECORD date/time and pressures as indicated by the following gauges:}
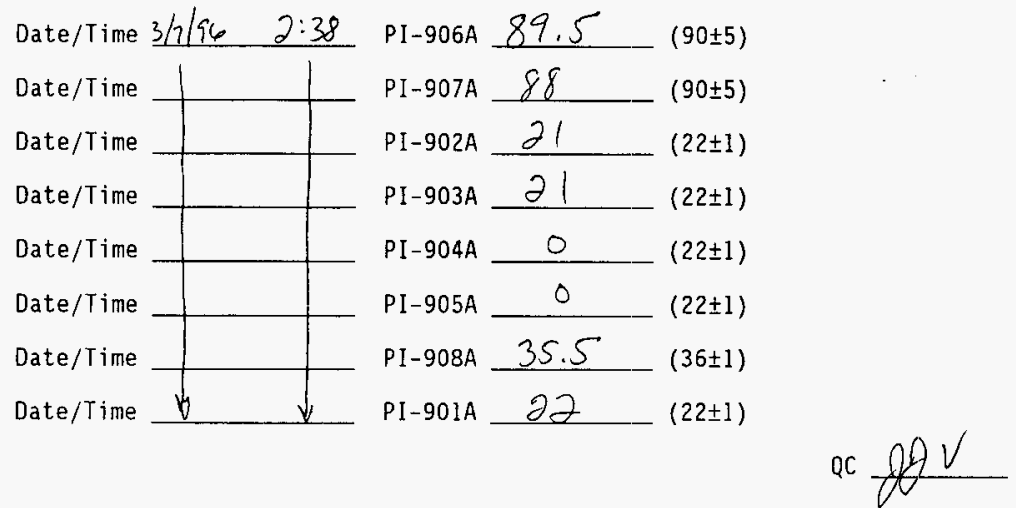

4.6 After 10 minutes has passed, record date/time and pressure:

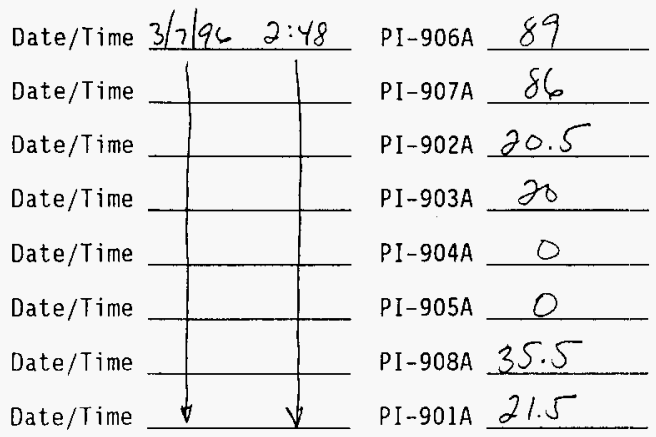

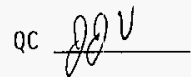

ACCEPTANCE CRITERIA: Pressure shall not drop by more than 5\% from sitep 4.5 to 4.6. for any of the respective gauges. If leaks exist, repair and repeat test steps from step 3.1 .

The test has been performed in accordance with the procedure. Any leaks identified during testing have been corrected and a retest has been satisfactorily performed.

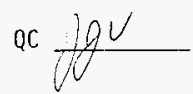


WHC-SD-WM-ATR-BD Gu

4.7 DRAIN pressure from system by OPENING the following valves:

- V-907A

- V-906a

- $\quad V-905 A$

- $\quad V-937 A$

5.0 TEST EXCEPTIONS

5.1 This test has been performed $X$ with, without exceptions.

See attached sheet (s) for test exceptions and resolution.

5.2 All exceptions have been dispositioned and accepted.
Cog. Engr. I fly M $3 / 20 / 96$

QC $10 \mathrm{~V} 3 / \mathrm{wa}$

$A-5$ 
WHE-SD WIM-ATR- 17 R RI

PUMPING AND INSTRUMENTATION CONTROL SYSTEM (PICS)

TEST EXCEPTIONS

TEST EXCEPTION NUMBER:

Procedure Step: 3.8 Tank ID: $A X-101$ skid ID: I

Description of Problem:

DP CELL SALW-CT-803H WAS NOT FUNCTIONING. THE MINIMUM WATER LEVEL OF 10 " COULD NOT BEVERIFIED.

Exception Resolution:

DP CELL (TRANSFERRED FROM A-10I SKID) DTS NOT FUNCTION CORRECTLY QUE TO SUSPECTED SOFTWARE JUMPER ON DP CELL PRESENCE OF WATER IN TANK WAS DETECTED BY AUDIBLE METHODS. NU RETEST IS RFQUTZED BASED ON PREVIOUS LEAK TESTS USING ONLY PNEUMATIC PRESSURE IN SAME LINES
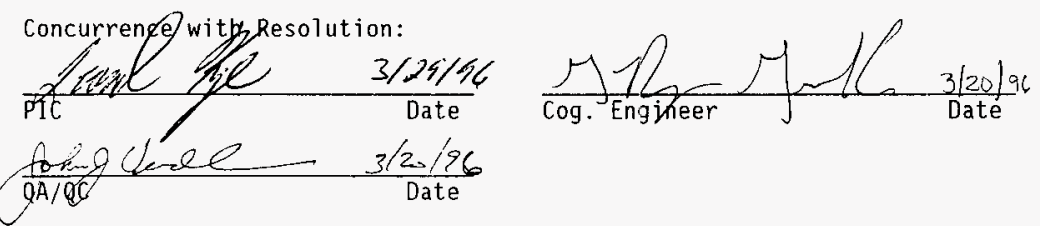

Retest Required:

Acceptable Retest Performed. Exception Resolved

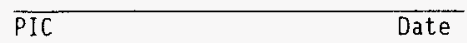
NO, $N / A$

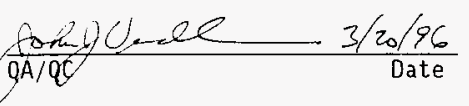

A- 6 


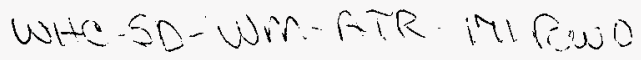

PUMPING AND INSTRUMENTATION CONTROL SYSTEM (PICS)

TEST EXCEPTIONS

TEST EXCEPTION NUMBER: 2

Procedure Step: 4,3 Tank ID: $A X-10 /$ Skid ID:

Description of Problem:

VALVE SALW-V-9OYA HAD TO BE CLOSED TO HOLD PRESSURE BECAUSE SALW-LY-9OIA HAS AN EXTERNAL VENT AND IS NOT CAPABLE OF MAINTAINING NORMAL OPERATING PRESSURE (B COMPONENT DESIGN)

Exception Resolution:

IT IS ACCEPTABLE TO CLOSE VALUE SAL- $-904 A$ DUE TO THE EXTERNAL VENT ON THE IP CONVERTER. LEAKS IN DOWNSTREAM PORTION OF SYSTEM WI BE DETECTED DURING THE OT IN THE FIELD.
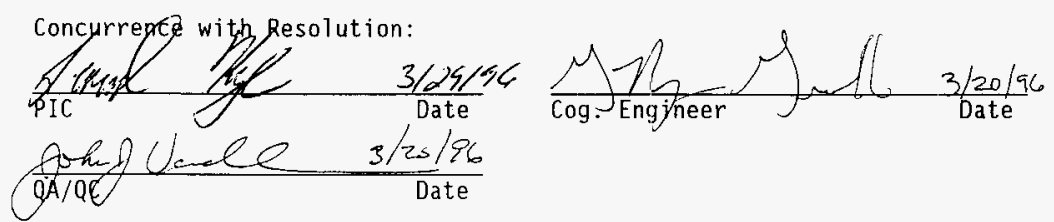

Retest Required:

Acceptable Retest Performed Exception Resolved
YES, $X$ NO, YES,

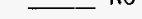

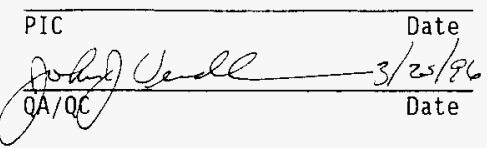

A-7 


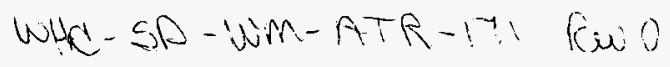

PUMPING AND INSTRUMENTATION CONTROL SYSTEM (PICS)

TEST EXCEPTIONS

TEST EXCEPTION NUMBER: 3

Procedure Step: 4.5 Tank ID: $A x-10 /$ Skid ID: $I$

Description of Problem:

PRESSURE AT PI-9OYA READ OPSIG. PRESSURE of $22 \pm 1$ SIG IS REQUIRED (STEP YT)

Exception Resolution:

PRESsURE AT PI-9O4A SHOULD READ OPSIG, DUR TU TEST STEPS 3.7 EQUALIZING VALVES.
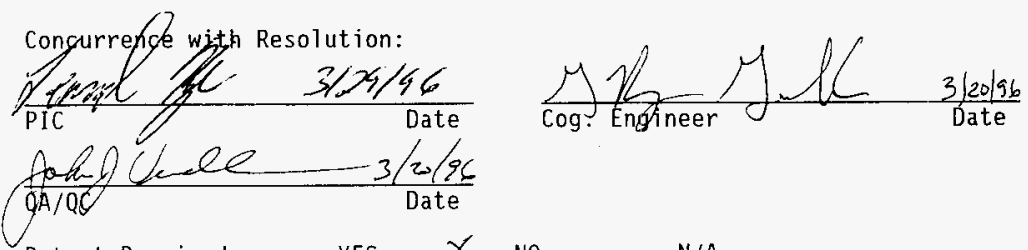

Retest Required: YES,

Acceptable Retest Performed: Exception Resolved YES, $N / A$ NO
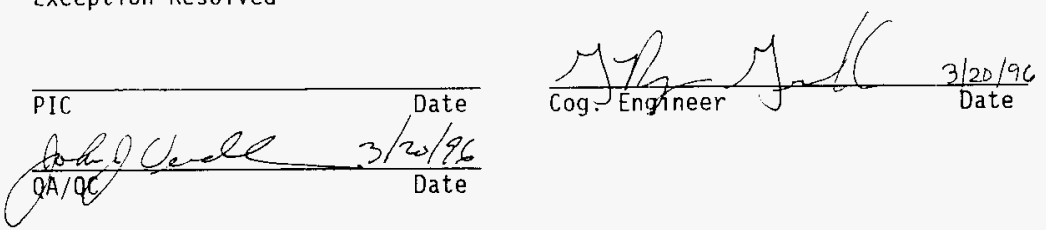

A. 8 


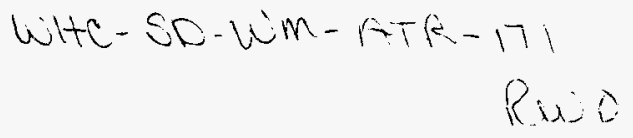

PUMPING AND INSTRUMENTATION CONTROL SYSTEM (PICS)

TEST EXCEPTIONS

TEST EXCEPTION NUMBER: 4

Procedure Step: 4.5 Tank ID: $A \times-10 /$ Skid ID: $I$

Description of Problem:

Pressure at PI-gOSA READ OPSIG. Pressure of $22 \pm 1$ PSIG IS REQUIRED (STEP 4.3)

Exception Resolution:

PRESSURE AT $905 A$ WILL READ $\varnothing$ PSI DUE TO CLOSING OF SALW-V- 9 VA AS NOTED IN EXCEPTION $\$ 2$,
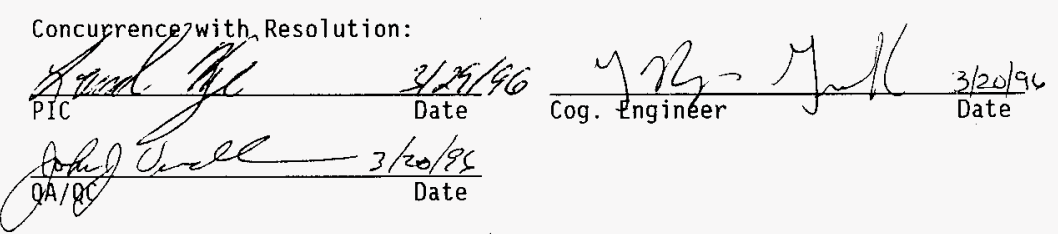

Retest Required:

Acceptable Retest Performed:

Exception Resolved
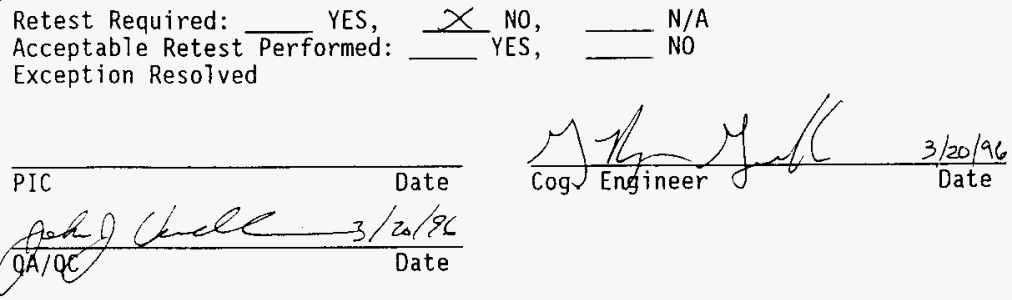

$$
\text { A- } 9
$$

